\title{
Novel prodrugs of meropenem with two lipophilic promoieties: synthesis and pharmacokinetics
}

\author{
Shunkichi Tanaka, Hiroshi Matsui, Masayasu Kasai, Kazuyoshi Kunishiro, Nobuharu Kakeya and \\ Hiroaki Shirahase
}

To improve the oral absorption of meropenem (MEPM), we synthesized and evaluated a series of its double-promoiety prodrugs, in which lipophilic promoieties were introduced into carboxyl and pyrrolidinyl groups. Among these prodrugs, pivaloyloxymethyl $(1 R, 5 S, 6 S)$-2-[(3S,5S)-5-( $N, N$-dimethylcarbamoyl)-1-(isobutyryloxymethyloxycarbonyl)pyrrolidin-3-ylthio]-6-[(1R)-1-hydroxyethyl]1-methylcarbapen-2-em-3-carboxylate (4) and 1-ethylpropyloxycarbonyloxymethyl $(1 R, 5 S, 6 S)$-2-[(3S,5S)-5-( $N, N$-dimethylcarbamoyl)1-(isobutyryloxymethyloxycarbonyl)pyrrolidin-3-ylthio]-6-[(1R)-1-hydroxyethyl]-1-methylcarbapen-2-em-3-carboxylate (8) were chosen for further evaluation. Compounds 4 and 8 were well absorbed after oral administration to rats and beagles (bioavailability 18.2-38.4\%), and expected to show potent therapeutic efficacy in patients infected with various pathogens, such as penicillin-resistant $\boldsymbol{S}$. pneumoniae and $\beta$-lactamase-negative ampicillin-resistant $\boldsymbol{H}$. influenzae.

The Journal of Antibiotics (2011) 64, 233-242; doi:10.1038/ja.2010.164; published online 12 January 2011

Keywords: carbapenem; double-promoiety prodrug; meropenem; single-promoiety prodrug

\section{INTRODUCTION}

Carbapenems are the most potent class of $\beta$-lactam antibiotics, which have a broad spectrum of potent antibacterial activities against Grampositive and Gram-negative organisms, including $P$. aeruginosa. ${ }^{1,2}$ Carbapenems are stable to hydrolysis by various $\beta$-lactamase, and thus, effective against most cephalosporin-resistant microorganisms. ${ }^{3-5}$ Imipenem, panipenem and meropenem (MEPM) have long been used for serious infectious diseases, including complicated urinary tract infection and complicated respiratory tract infection (Figure 1). ${ }^{1}$ Recently, doripenem has been launched as a new potent carbapenem (Figure 1). ${ }^{6}$ However, these are all for parenteral use only. Imipenem and panipenem are unstable chemically and to renal dehydropeptidase-I, and are thus used in combination with cilastatin and betamipron, respectively. MEPM and doripenem have a $1 \beta$-methyl group, and are stable against chemical degradation and hydrolysis by dehydropeptidase-I, ${ }^{7-9}$ and are thus used without cilastatin or betamipron.

All these parenteral carbapenems have a carboxyl group at the carbapene C-3 position, which is essential for interaction with a target protein, penicillin-binding protein, ${ }^{1}$ and a basic group at the pyrrolidine $\mathrm{N}-1$ position, which promote their invasion through $\mathrm{D} 2$ porin into $P$. aeruginosa, ${ }^{10}$ resulting in little oral absorption because of the two ionizable groups. Many attempts to find new orally active carbapenems have been reported, ${ }^{11,12}$ in which the basic group at the pyrrolidine N-1 position was eliminated and the carboxyl group was esterified by easily hydrolizable promoiety to increase oral absorption, but most showed very weak antibacterial activity against
P. aeruginosa. Recently, tebipenem was developed in Japan and approved as a new orally active carbapenem (Figure 1). Tebipenem showed potent activity against penicillin-resistant S. pneumoniae, $\beta$-lactamase-negative ampicillin-resistant $H$. influenzae, $H$. influenzae and E. coli; ${ }^{13-15}$ however, unlike MEPM, tebipenem has no activity against $\beta$-lactamase-producing $P$. aeruginos $a^{2}$ and its therapeutic use is still limited to pediatric otitis media, rhinitis and pneumonia. In the present study, we attempted to increase the oral bioavailability of MEPM by chemical modification to a double-promoiety prodrug, because MEPM is chemically and biologically more stable than imipenem and panipenem, and has a lower molecular weight than doripenem. Furthermore, its efficacy in infection therapy and safety have been established. ${ }^{16}$

We have reported the successful modification of ceftizoxime, a parenteral cephalosporin, to a double-promoiety prodrug with lipophilic and hydrophilic promoieties. ${ }^{17,18}$ Here, double-promoiety prodrugs of MEPM, in which two kinds of lipophilic promoieties were introduced at the carbapene $\mathrm{C}-3$ and pyrrolidine $\mathrm{N}-1$ position of MEPM to increase oral bioavailability, were synthesized and biologically evaluated.

\section{Drug design}

First, single-promoiety prodrugs of MEPM were designed using pivaloyloxymethyl (POM) and 1-ethylpropyloxycarbonyloxymethyl (EPC), as shown in Figure 2. $\beta$-Lactam antibiotics, such as penicillins, cephalosporins and carbapenems, have a carboxyl group that decreases their membrane permeability, resulting in low oral absorption. In many 
<smiles>CC(=O)[C@H]1CC(SC2=C(C(=O)O)N3C(=O)[C@H](C(C)O)[C@@H]3[C@@H]2C)CN1</smiles>

Meropenem (MEPM)<smiles>CC(O)[C@H]1C(=O)N2C(C(=O)O)=C(SCCNC=N)C[C@H]12</smiles>

Imipenem<smiles>CC(=N)N1CC[C@H](SC2=C(C(=O)O)N3C(=O)[C@H](C(C)O)[C@H]3C2)C1</smiles>

Panipenem<smiles>CC(O)[C@H]1C(=O)N2C(C(=O)O)=C(S[C@@H]3CNC(CNS(N)(=O)=O)C3)C(C)[C@@H]12</smiles>

Doripenem<smiles>CC(O)[C@H]1C(=O)N2C(C(=O)O)=C(SC3CN(C4=NCCS4)C3)[C@H](C)[C@H]12</smiles>

Tebipenem

Figure 1 Chemical structures of carbapemems.

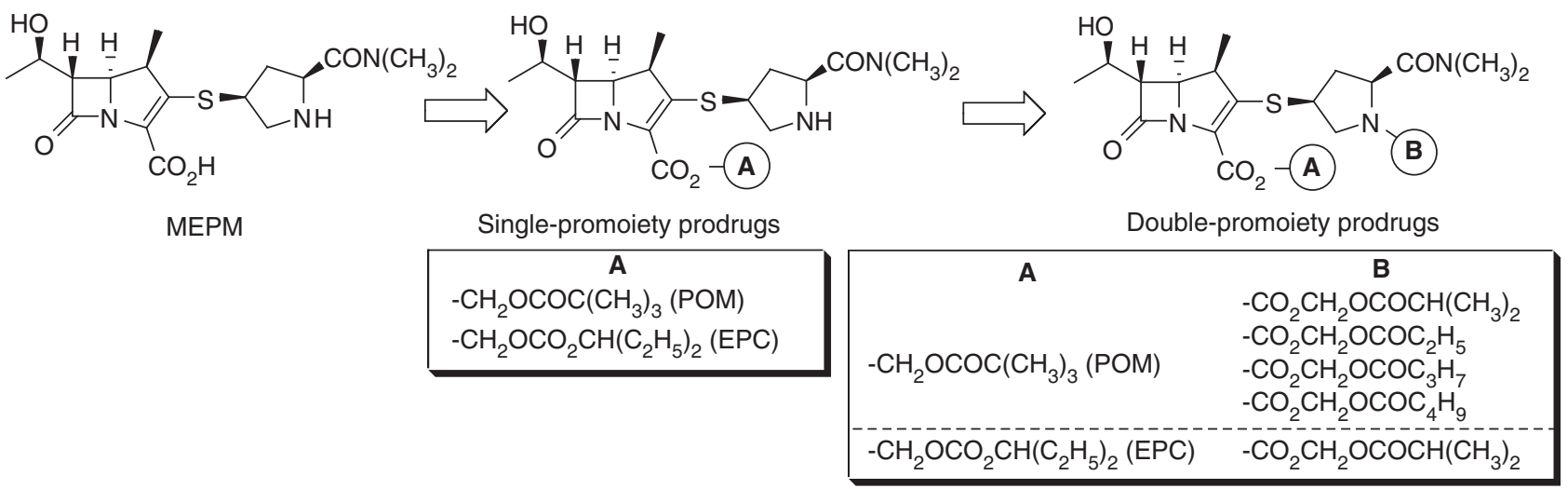

Figure 2 Drug design.

orally used penicillins and cephalosporins, their carboxyl group is esterified with a lipophilic and hydrolyzable promoiety: these prodrugs are efficiently absorbed and then rapidly hydrolyzed to an active form. As such a promoiety, POM is used in pivmecillinam, cefteram, cefetamet, cefditoren and cefcapene; however, a POM promoiety in cephalosporins has been reported to decrease plasma carnitine levels in children. ${ }^{19}$ As a non-POM promoiety, carbonate-type promoieties have been used: 1-(cyclohexyloxycarbonyloxy)ethyl and 1-(isopropyloxycarbonyloxy)ethyl in cefotiam and cefpodoxime, respectively, both racemic promoieties. Here, we chose EPC without an asymmetric carbon as a non-POM promoiety for a prodrug.

Second, double-promoiety prodrugs of MEPM were designed by introduction of the second lipophilic promoiety to the pyrrolidine $\mathrm{N}-1$ position of MEPM (Figure 2) because no single-promoiety prodrugs of parenteral carbapenems have been successfully developed, probably due to their basic side chain, which is also considered to decrease their membrane permeability. As the second lipophilic promoiety, carbonate promoieties (isobutyryloxymethyloxycarbonyl, propionyloxymethyloxycarbonyl, butyryloxymethyloxycarbonyl and valeryloxymethyloxycarbonyl) were used.

\section{Chemistry}

The general synthetic routes of prodrugs of MEPM are shown in Scheme 1. All prodrugs were prepared from MEPM. Singlepromoiety prodrugs $\mathbf{1}$ and $\mathbf{2}$ were prepared by esterification with the corresponding alkyl iodides, and 3 was afforded by $\mathrm{N}$ alkylation of pyrrolidine moiety. ${ }^{20}$ Double-promoiety prodrugs 4-10 were prepared by $\mathrm{N}$-alkylation and esterification in one pot, as described above.

Other synthetic routes of compounds $\mathbf{4}$ and $\mathbf{8}$ are shown in Scheme $2-4$. In Scheme 2, introduction of 1-isobutyryloxymethyl $(2 S, 4 S)-2-N$, $\mathrm{N}$-dimethylcarbamoyl-4-mercaptopyrrolidine-1-carboxylate $(\mathrm{BMP})^{21}$ to $p$-nitrobenzyl $(1 R, 5 S, 6 S)$-2-diphenylphosphoryl-6-[(1R)-1-hydroxyethyl]-1-methylcarbapen-2-em-3-carboxylate (MAP) at the carbapene C-2 position was achieved to give $\mathbf{1 1}$ in accordance with the literature. ${ }^{22} p$-Nitrobenzyl moiety of $\mathbf{1 1}$ was removed by Pd-C catalyzed hydrogenation to yield a carboxylic acid derivative, which was esterified with POM-I and EPC-I in the presence of benzyl triethylammonium chloride (BTEAC) to give compounds $\mathbf{4}$ and $\mathbf{8}$, respectively.

In Scheme 3, compound 4 was prepared from $(3 S, 4 S)-3-[(1 R)-$ ( $t$-butyldimethyl-silyloxy)ethyl $]-4$-[(1R)-1-carboxyethyl]-2-azetidinone ( $\beta$-MAC). The $\beta$-MAC was esterified with a magnesium salt of POMesterified malonate using $1,1^{\prime}$-carbonyldiimidazole (CDI) as a condensing reagent to give 12 . Compound 12 was treated with $p$-dodecylbenzenesulfonyl azide to give $\alpha$-diazoester 13, which was then cyclized with rhodium catalyst, and the product was phosphorylated to give $14 .^{22}$ Compound 14 was treated with BMP to give 15, from which the tert-butyldimethylsilyl (TBS) group was removed by $\mathrm{Et}_{3} \mathrm{~N} \cdot 3 \mathrm{HF}$ to give 4 .

In Scheme 4 , the carboxyl moiety of $\beta$-MAC was converted to thioester of BMP using 1-ethyl-3-(dimethylaminopropyl)carbodiimide hydrochloride (EDC) and $N$-methylmorpholine to give 16. Acylation of 16 with EPC ester of oxalic acid afforded 17, which was reacted with 


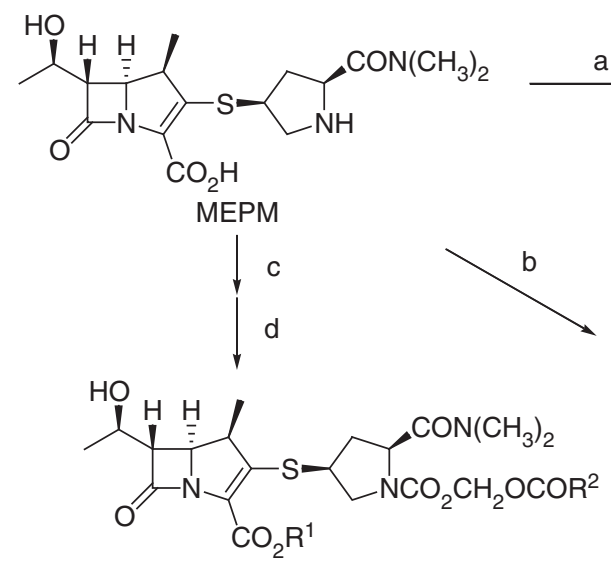<smiles>CC(=O)C1CC(SC2=C(C(=O)O)N3C(=O)C(C(C)O)[C@H]3C2C)CN1</smiles>

1: $\mathrm{R}^{1} ;-\mathrm{CH}_{2} \mathrm{OCOC}\left(\mathrm{CH}_{3}\right)_{3}$

2: $\mathrm{R}^{1} ;-\mathrm{CH}_{2} \mathrm{OCO}_{2} \mathrm{CH}\left(\mathrm{C}_{2} \mathrm{H}_{5}\right)_{2}$

$\mathrm{R}^{1}$

$4-\mathrm{CH}_{2} \mathrm{OCOC}\left(\mathrm{CH}_{3}\right)_{3}$

$5-\mathrm{CH}_{2} \mathrm{OCOC}\left(\mathrm{CH}_{3}\right)_{3}$

$6-\mathrm{CH}_{2} \mathrm{OCOC}\left(\mathrm{CH}_{3}\right)_{3}$

$7-\mathrm{CH}_{2} \mathrm{OCOC}\left(\mathrm{CH}_{3}\right)_{3}$

$8-\mathrm{CH}_{2} \mathrm{OCO}_{2} \mathrm{CH}\left(\mathrm{C}_{2} \mathrm{H}_{5}\right)_{2}$

$9-\mathrm{CH}\left(\mathrm{CH}_{3}\right) \mathrm{OCO}_{2}-\mathrm{C}_{6} \mathrm{H}_{11}$

$10-\mathrm{CH}\left(\mathrm{CH}_{3}\right) \mathrm{OCO}_{2} \mathrm{CH}\left(\mathrm{CH}_{3}\right)_{2}$
$\mathrm{R}^{2}$<smiles>CC(=O)OCOC(=O)OC(C)C</smiles>

3

Scheme 1 Synthesis of prodrugs of MEPM.

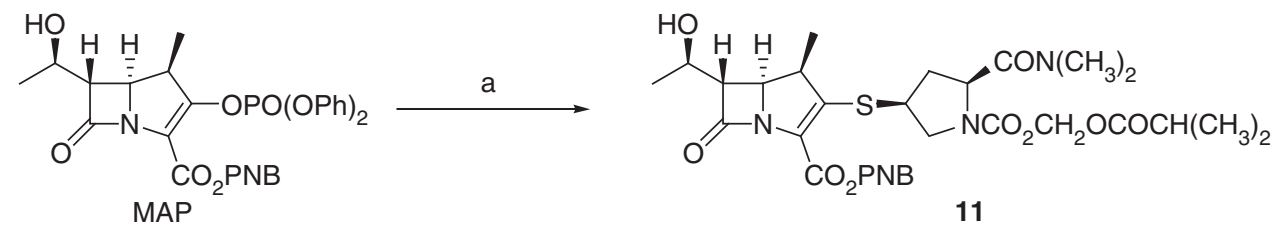

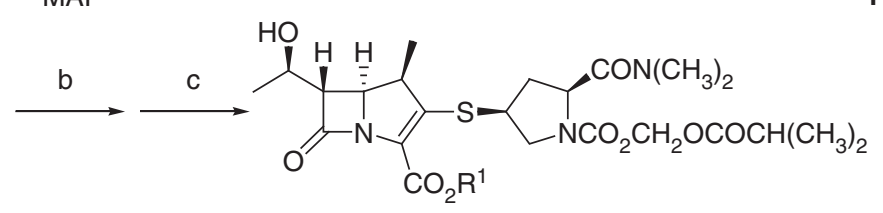

4: $\mathrm{R}^{1} ;-\mathrm{CH}_{2} \mathrm{OCOC}\left(\mathrm{CH}_{3}\right)_{3}$

8: $\mathrm{R}^{1} ;-\mathrm{CH}_{2} \mathrm{OCO}_{2} \mathrm{CH}\left(\mathrm{C}_{2} \mathrm{H}_{5}\right)_{2}$

PNB: $p$-nitrobenzyl

Reagents, conditions and yields: (a) BMP, $i-\mathrm{Pr}_{2} \mathrm{NEt}, \mathrm{CH}_{3} \mathrm{CN}, 5^{\circ} \mathrm{C}, 92 \%$;

(b) $\mathrm{H}_{2}, \mathrm{Pd}-\mathrm{C}$, THF-0.1M MOPS Buffer ( $\mathrm{pH} 7.0$ ), $35^{\circ} \mathrm{C}$;

(c) POM-I or EPC-I, BTEAC, $\mathrm{CH}_{2} \mathrm{Cl}_{2}-\mathrm{MOPS}$ Buffer ( $\mathrm{pH} 7.0$ ), rt, 82 or $83 \%$, 2 steps.

Scheme 2 Synthesis of $\mathbf{4}$ and $\mathbf{8}$ from MAP.

diethoxymethyl phosphine in toluene, and cyclized by heat to give $\mathbf{1 8}$. Finally, the TBS group of $\mathbf{1 8}$ was removed to give $\mathbf{8}$, as described in Scheme 3.

\section{RESULTS}

Physicochemical properties and oral absorption of single- and double-promoiety prodrugs of MEPM

$\operatorname{LogD}(\mathrm{pH} 7.0$ ), water solubility ( $\mathrm{pH} 7.0$ ) and oral absorption of MEPM and its single- and double-promoiety prodrugs are shown in Table 1. Plasma concentrations of MEPM were determined 30, 60 and $180 \mathrm{~min}$ after oral administration of MEPM or prodrugs in male rats. Bioavailabilities were calculated by comparing AUC values of MEPM after intravenous administration of MEPM and oral administration of MEPM or prodrugs. In comparison with MEPM, single-promoiety prodrugs with POM (1) or EPC (2) at the carbapene C-3 position showed moderately higher $\log \mathrm{D}$ values and comparable high water solubility. The Cmax and bioavailability were increased moderately in $\mathbf{1}$ and slightly in 2 . A single-promoiety prodrug 3 with isobutyryloxymethyloxycarbonyl at the pyrrolidine $\mathrm{N}-1$ position was also synthesized; however, there was little effect on the LogD, Cmax and bioavailability. 


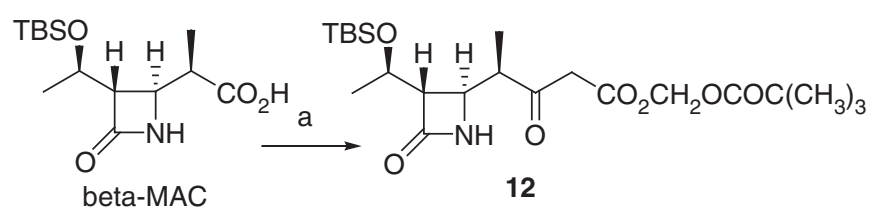<smiles>CC(C)OCOC(=O)C(=N)OCOC(C)(C)C</smiles>

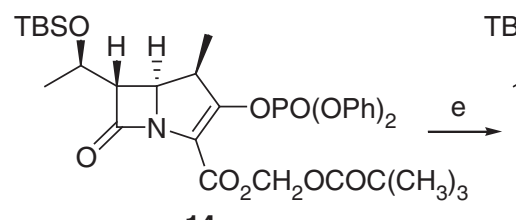

14<smiles>CC(=O)OCOC(C)=O</smiles>

15<smiles>COC(=O)OCOC(C)=O</smiles>

Reagents, conditions and yields:

(a) $\mathrm{CDI}, \mathrm{Mg}\left[\mathrm{OCOCH}_{2} \mathrm{CO}_{2} \mathrm{CH}_{2} \mathrm{OCOC}\left(\mathrm{CH}_{3}\right)_{3}\right]_{2}, \mathrm{CH}_{3} \mathrm{CN}$, rt to $40^{\circ} \mathrm{C}, 12 \%$;

(b) p-dodecylbenzenesulfonyl azide, $\mathrm{Et}_{3} \mathrm{~N}, \mathrm{CH}_{3} \mathrm{CN}, 0^{\circ} \mathrm{C}, 85 \%$;

(c) $\left[(\mathrm{AcO})_{2} \mathrm{Rh}\right]_{2} \cdot 2 \mathrm{H}_{2} \mathrm{O}, \mathrm{AcOEt}, 50^{\circ} \mathrm{C}$;

(d) $(\mathrm{PhO})_{2} \mathrm{P}(\mathrm{O}) \mathrm{Cl}, i-\mathrm{Pr}_{2} \mathrm{NEt}, \mathrm{CH}_{3} \mathrm{CN}, 0^{\circ} \mathrm{C}, 77 \%$, 2 steps;

(e) BMP, $i-\mathrm{Pr}_{2} \mathrm{NEt}, \mathrm{CH}_{3} \mathrm{CN}, 0^{\circ} \mathrm{C}, 43 \%$; (f) $\mathrm{Et}_{3} \mathrm{~N} \cdot 3 \mathrm{HF}, \mathrm{DMF}, \mathrm{rt}, 17 \%$.

Scheme 3 Synthesis of 4 from $\beta-M A C$.

Introduction of a second lipophilic promoiety to the pyrrolidine $\mathrm{N}-1$ position increased $\log \mathrm{D}$ to $1.53-2.68$ and decreased water solubility to $51.8-846.5 \mu \mathrm{g} \mathrm{ml}^{-1}$ (4-8). Double-promoiety prodrugs with POM (4-7) showed similar Cmax and bioavailability. Compound 4 was chosen for further evaluation among compounds 4-7 as it was most stable in the preliminary stability test, in which the solid compounds were kept at $40{ }^{\circ} \mathrm{C}$ in a tightly capped glass bottle with silica gel for 2 weeks followed by determination of their purity. A double-promoiety prodrug with EPC (8) showed slightly lower Cmax and bioavailability than those of POM-type double-promoiety prodrugs. To further increase its Cmax and bioavailability, racemic promoieties 1-(cyclohexyloxycarbonyloxy)ethyl and 1-(isopropyloxycarbonyloxy)ethyl were introduced (9 and 10); however, little changed in $\mathbf{9}$ and rather decreased in 10. Compound $\mathbf{9}$, but not $\mathbf{8}$ was unstable in the preliminary stability test. Compound $\mathbf{8}$ was also chosen for further evaluation as a non-POM doublepromoiety prodrug.

\section{Pharmacokinetics of compounds 4 and 8 in rats and beagles} In male rats, the pharmacokinetics of MEPM after oral administration of compounds $\mathbf{4}$ and $\mathbf{8}$ was reevaluated to more precisely determine the parameters: blood was taken at 10, 20, 30, 45, 60, 90 and $120 \mathrm{~min}$ after administration. The Cmax was similar between compounds 4 and $\mathbf{8}$, and AUC and bioavailability were slightly higher and $\mathrm{T}_{1 / 2}$ was longer in compound 4 than 8 (Figure 3, Table 2). It was confirmed that oral absorption of MEPM was effectively increased in the double-promoiety prodrugs in comparison with the corresponding single-promoiety prodrugs ( 4 vs 1 and 8 vs 2 ).

In male beagles, the pharmacokinetics of compounds $\mathbf{4}$ and $\mathbf{8}$ were evaluated (Figure 4, Table 3). The Cmax was similar between compounds 4 and $\mathbf{8}$, and AUC and bioavailability were higher and $\mathrm{T}_{1 / 2}$ was longer in compound $\mathbf{4}$ than $\mathbf{8}$.

\section{DISCUSSION}

MEPM has potent and broad antibacterial activities, and has long been used clinically. Its efficacy and safety have been established, and thus, it is still a useful parenteral antibiotic. ${ }^{16}$ Development of orally active carbapenems has been desired because of the increase of microorganisms resistant to oral antibacterial agents, such as cephalosporin and fluoroquinolone; however, it is difficult to improve the oral absorption of parenteral carbapenems by conventional prodrug methods used in cephalosporin, such as cefuroxime, ${ }^{23}$ in which a carboxyl group was esterified, because carbapenems are chemically and biologically less stable than cephalosporins. Furthermore, their basic group, which is essential for anti-bacterial activities against P. aeruginosa,${ }^{10}$ is also considered to limit their oral absorption. Although some newly synthesized chemically and biologically stable carbapenems lacking a basic group were reported, ${ }^{11,12}$ no compounds have been successfully developed. Recently, tebipenem, showing high bioavailability and high activity against penicillinresistant $S$. pneumoniae and $\beta$-lactamase-negative ampicillin-resistant $H$. influenzae, was approved in Japan for pediatric otitis media, rhinitis 


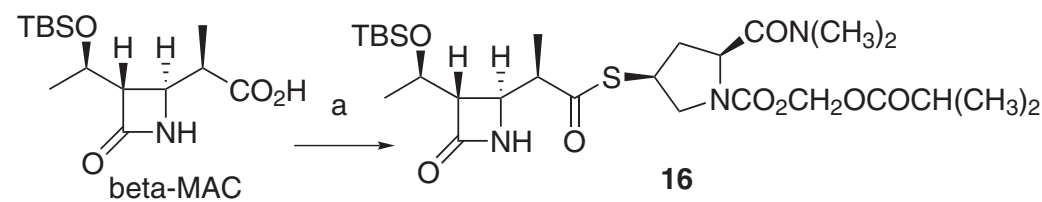

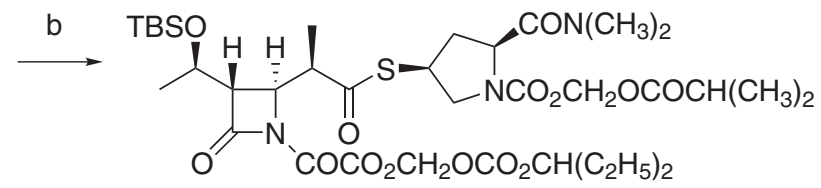

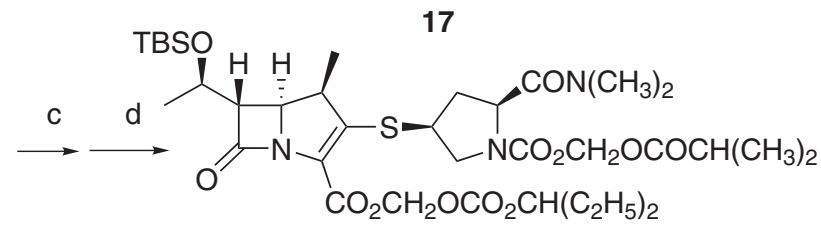

18

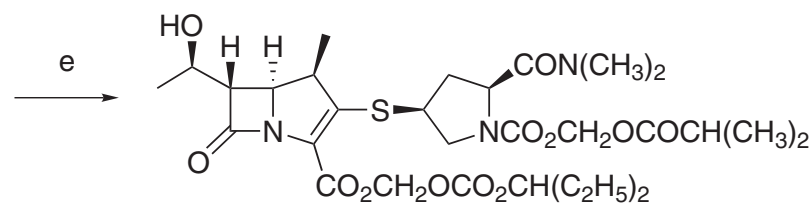

8

Reagents, conditions and yields:

(a) BMP, EDC, $N$-methylmorpholine, DMF, rt, $71 \%$;

(b) 1-ethylpropyloxycarbonyloxymethyloxyoxalyl chloride, $\mathrm{Et}_{3} \mathrm{~N}, \mathrm{CH}_{2} \mathrm{Cl}_{2}, 0^{\circ} \mathrm{C}, 60 \%$;

(c) $\mathrm{MeP}(\mathrm{OEt})_{2}$, toluene, rt; (d) xylene, 140 to $150^{\circ} \mathrm{C}, 53 \%, 2$ steps;

(e) $\mathrm{Et}_{3} \mathrm{~N} \cdot 3 \mathrm{HF}, \mathrm{DMF}, \mathrm{rt}, 72 \%$.

Scheme 4 Synthesis of 8 from $\beta-M A C$.

Table 1 Physicochemical properties and pharmacokinetics in rats of single- and double-promoiety prodrugs of MEPM

\begin{tabular}{|c|c|c|c|c|c|c|}
\hline Compound & $R^{1}$ & $R^{2}$ & $C \max \left(\mu g m^{-1}\right)$ & $B A(\%)$ & Water solubility $\left(\mu g \mathrm{ml}^{-1}\right)$ & $\log D$ \\
\hline MEPM & $\mathrm{H}$ & $\mathrm{H}$ & $0.24 \pm 0.13$ & 3.9 & $>1000$ & $<-2.5$ \\
\hline 1 & $\mathrm{CH}_{2} \mathrm{OCOC}\left(\mathrm{CH}_{3}\right)_{3}(\mathrm{POM})$ & $\mathrm{H}^{1)}$ & $0.74 \pm 0.32$ & 19.8 & $>1000$ & -0.52 \\
\hline 3 & $\mathrm{Na}$ & $\mathrm{CO}_{2} \mathrm{CH}_{2} \mathrm{OCOCH}\left(\mathrm{CH}_{3}\right)_{2}$ & $0.14 \pm 0.10$ & 3.4 & $>1000$ & $<-1$ \\
\hline 4 & $\mathrm{CH}_{2} \mathrm{OCOC}\left(\mathrm{CH}_{3}\right)_{3}(\mathrm{POM})$ & $\mathrm{CO}_{2} \mathrm{CH}_{2} \mathrm{OCOCH}\left(\mathrm{CH}_{3}\right)_{2}$ & $1.16 \pm 0.22$ & 27.5 & 130 & 2.00 \\
\hline 7 & & $\mathrm{CO}_{2} \mathrm{CH}_{2} \mathrm{OCOC}_{4} \mathrm{H}_{9}$ & $0.94 \pm 0.14$ & 27.0 & 154.9 & 2.68 \\
\hline 8 & $\mathrm{CH}_{2} \mathrm{OCO}_{2} \mathrm{CH}\left(\mathrm{C}_{2} \mathrm{H}_{5}\right)_{2}(\mathrm{EPC})$ & $\mathrm{CO}_{2} \mathrm{CH}_{2} \mathrm{OCOCH}\left(\mathrm{CH}_{3}\right)_{2}$ & $0.89 \pm 0.33$ & 18.8 & 51.8 & 2.51 \\
\hline 9 & $\mathrm{CH}\left(\mathrm{CH}_{3}\right) \mathrm{OCO}_{2}-\mathrm{C}_{6} \mathrm{H}_{11}$ & & $1.00 \pm 0.51$ & 16.9 & 121.9 & 2.86 \\
\hline 10 & $\mathrm{CH}\left(\mathrm{CH}_{3}\right) \mathrm{OCO}_{2} \mathrm{CH}\left(\mathrm{CH}_{3}\right)_{2}$ & & $0.65 \pm 0.12$ & 15.4 & 772.5 & 1.81 \\
\hline
\end{tabular}

Abbreviations: BA, bioavailability; EPC, 1-ethylpropyloxycarbonyloxymethyl; MEPM, meropenem; POM, pivaloyloxymethyl.

a HCl salt, Cmax; Mean \pm s.d. $(n=3)$, Water solubility (pH 7.0) and LogD ( $\mathrm{pH} 7.0)$; Mean $(n=2)$.

and pneumonia. ${ }^{13-15}$ In the present study, we attempted to apply our double-promoiety prodrug method to MEPM to increase its bioavailability. We succeeded in modifying ceftizoxime, a parenteral cephalosporin, to orally bioavailable double-promoiety prodrugs, in which the appropriate balance of lipophilicity and hydrophilicity was achieved by the introduction of both lipophilic promoiety and hydrophilic promoiety. ${ }^{17,18}$ In MEPM, conventional esterification of the carboxyl group is not enough to achieve appropriate lipophilicity because of the presence of a basic group. Indeed, compound 1 with POM and compound 2 with EPC at the carbapene C-3 position still had low lipophilicity and were highly water soluble, and thus their oral absorption was little or only slightly increased. However, in addition, introduction of a second lipophilic group, which is known to be hydrolyzable and useful in promoieties, at the pyrrolidine N-1 position increased lipophilicity and decreased water solubility, and markedly enhanced Cmax and AUC compared with the corresponding 


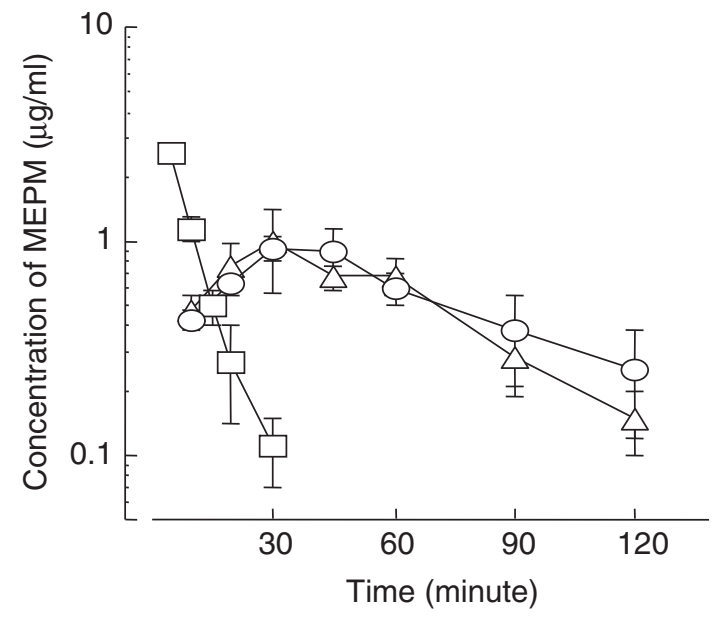

Figure 3 Plasma concentrations of MEPM after oral administration of compounds 4 and $\mathbf{8}$ at a dose of $20 \mathrm{mg}$ potency per $\mathrm{kg}$ and intravenous administration of MEPM at a dose of $2 \mathrm{mg}$ potency per $\mathrm{kg}$ to male SD rats. Mean \pm s.d. $(n=4)$; $\bigcirc$, compound 4 p.o.; $\triangle$, compound 8 p.o.; $\square$, MEPM i.v.

Table 2 Pharmacokinetic profile of MEPM after oral administration of compounds 4 and 8 at a dose of $20 \mathrm{mg}$ potency per $\mathrm{kg}$ and intravenous administration of MEPM at a dose of $2 \mathrm{mg}$ potency per kg to male SD rats

\begin{tabular}{lcccc}
\hline Compound & $C \max \left(\mu \mathrm{gml^{-1 }}\right)$ & $T_{1 / 2}(\mathrm{~min})$ & $A \cup C\left(\mu \mathrm{gmin} \mathrm{I}^{-1}\right)$ & $B A(\%)$ \\
\hline 4 & $0.96 \pm 0.18$ & $47.8 \pm 24.3$ & $82.1 \pm 21.5$ & 23.4 \\
8 & $1.05 \pm 0.26$ & $24.8 \pm 4.40$ & $63.9 \pm 7.04$ & 18.2 \\
MEPM & - & $4.53 \pm 0.46$ & $35.1 \pm 1.88$ & - \\
\hline
\end{tabular}

Abbreviations: BA, bioavailability; MEPM, meropenem. Mean \pm s.d. $(n=4)$.

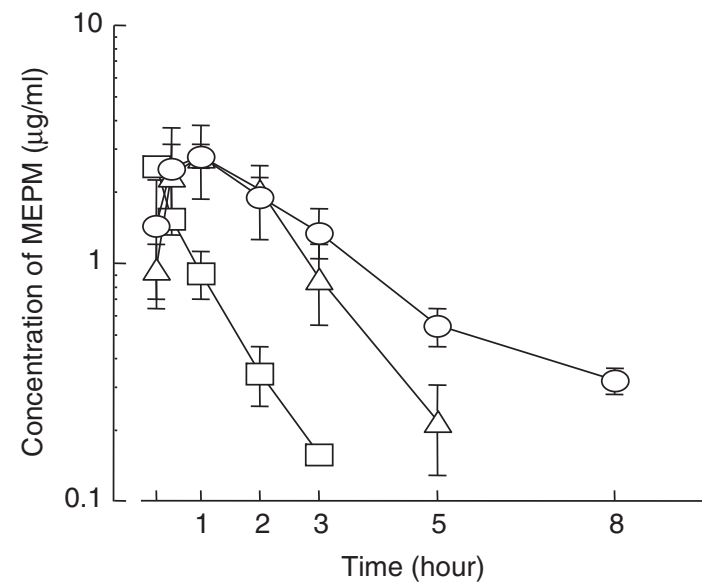

Figure 4 Plasma concentrations of MEPM after oral administration of compounds 4 and 8 at a dose of $10 \mathrm{mg}$ potency per $\mathrm{kg}$ and intravenous administration of MEPM at a dose of $1 \mathrm{mg}$ potency per $\mathrm{kg}$ to male beagles. Mean \pm s.d. $(n=4)$; $\bigcirc$, compound 4 p.o.; $\triangle$, compound 8 p.o.; $\square$, MEPM i.v.

single-promoiety prodrugs. Among them, compounds $\mathbf{4}$ and $\mathbf{8}$ showed similar Cmax in rats and beagles $\left(0.96-2.92 \mu \mathrm{g} \mathrm{ml}^{-1}\right)$, which were higher than the minimum inhibitory concentration of MEPM against penicillin-resistant S. pneumoniae, $H$. influenzae and E. coli. Their bioavailabilities in animals are relatively low compared with clinically
Table 3 Pharmacokinetic profile of MEPM after oral administration of compounds 4 and 8 at a dose of $10 \mathrm{mg}$ potency per $\mathrm{kg}$ and intravenous administration of MEPM at a dose of $1 \mathrm{mg}$ potency per kg to male beagles

\begin{tabular}{lcccc}
\hline Compound & $C \max \left(\mu \mathrm{gml^{-1 }}\right)$ & $T_{1 / 2}(h)$ & $A \cup C\left(\mu g \mathrm{ml}^{-1}\right)$ & $B A(\%)$ \\
\hline $\mathbf{4}$ & $2.86 \pm 1.02$ & $2.30 \pm 0.53$ & $11.8 \pm 0.22$ & 38.4 \\
$\mathbf{8}$ & $2.92 \pm 0.39$ & $1.04 \pm 0.17$ & $7.50 \pm 1.17$ & 24.4 \\
MEPM & - & $0.70 \pm 0.07$ & $3.08 \pm 0.26$ & - \\
\hline
\end{tabular}

Abbreviations: BA, bioavailability; MEPM, meropenem. Mean \pm s.d. $(n=4)$.

used cephalosporins; however, double-promoiety prodrugs including ceftizoxime alapivoxil, showed higher urinary recovery in humans than rats or beagles (more than twofold). ${ }^{17,24}$ Compounds $\mathbf{4}$ and $\mathbf{8}$ are also expected to show higher bioavailability in humans than animals, and to show potent anti-infection effects in patients. Indeed, the dosage regimen of compound $\mathbf{8}$ in mice for the simulation of the predicted human pharmacokinetics significantly reduced viable cell counts in the lungs of mice intranasally infected with three strains of drug-resistant S. pneumoniae. ${ }^{25}$ Whereas compound 4 showed longer $\mathrm{T}_{1 / 2}$ than $\mathbf{8}$, the POM moiety of $\mathbf{4}$ might decrease plasma carnitine levels in children, as reported previously for cephalosporins. ${ }^{19}$ To select a candidate for clinical study, further study is needed to precisely determine their pharmacokinetic properties, safety and therapeutic efficacy in various infectious models, including respiratory tract infection and urinary tract infection models. Compounds $\mathbf{4}$ and $\mathbf{8}$ would be the first orally active carbapenems effective against $P$. aeruginosa, derived from a parenteral antibiotic, which could be also useful in switch therapy from injection of MEPM to oral administration.

In conclusion, MEPM was successfully modified to double-promoiety prodrugs with excellent oral absorption by the introduction of two lipophilic promoieties on two sides. This method is thought to be applicable to other small parenteral drugs with low oral absorption because of two or more ionizable promoieties.

\section{EXPERIMENTAL PROCEDURE}

\section{General procedure}

Chemicals were obtained from commercial sources and used without purification. Reactions were monitored by TLC on Merck precoated silica gel $60 \mathrm{~F}_{254}$ $(0.25 \mathrm{~mm}$, Merck, Darmstadt, Germany) plates. The spots on TLC were visualized by UV light $(254 \mathrm{~nm})$, iodine and ninhydrin. Column chromatography was performed on silica gel (Daisogel NO.1001W; Daiso, Osaka, Japan) or HP-21 (Diaion; Mitsubishi Chemical, Tokyo, Japan). Melting points were measured on a melting point apparatus (MP-21; Yamato Scientific, Tokyo, Japan) and are uncorrected. IR spectra were obtained with an infrared spectrometer (FT-720; HORIBA, Kyoto, Japan or FT-IR8200PC; Shimadzu, Kyoto, Japan). ${ }^{1} \mathrm{H}-\mathrm{NMR}$ spectra were recorded at $400 \mathrm{MHz}$ (JNM-AL400; JEOL, Tokyo, Japan) or $90 \mathrm{MHz}$ (Hitachi FT-NMR R-1900; Hitachi HighTechnologies, Tokyo, Japan) on a nuclear magnetic resonance spectrometer using tetramethylsilane as an internal standard. Mass spectra (MS) were obtained on a QTRAP LC/MS/MS system (API2000; Applied Biosystems, Foster City, CA, USA).

\section{Synthetic procedures in Scheme 1}

Pivaloyloxymethyl (1R,5S,6S)-2-[(3S,5S)-5-(N,N-Dimethylcarbamoyl)pyrrolidin3-ylthio]-6-[(1R)-1-hydroxyethyl]-1-methylcarbapen-2-em-3-carboxylate Hydrochloride (1). To a suspension of MEPM $(5.98 \mathrm{~g}, 15.6 \mathrm{mmol})$ in $\mathrm{N}, \mathrm{N}$-dimethylformamide (DMF) $(27 \mathrm{ml})$ at $5^{\circ} \mathrm{C}$ were added pivaloyloxymethyl iodide $(8.4 \mathrm{~g}$, $31 \mathrm{mmol})$ and $\mathrm{K}_{2} \mathrm{CO}_{3}(2.59 \mathrm{~g}, 18.7 \mathrm{mmol})$, and the mixture was stirred at 
$5-10^{\circ} \mathrm{C}$ for $0.5 \mathrm{~h}$, followed by the addition of pivaloyloxymethyl iodide $(2.5 \mathrm{~g}$, $9.4 \mathrm{mmol}$ ), and stirring at the same temperature for $0.5 \mathrm{~h}$. The mixture was poured into $\mathrm{Et}_{2} \mathrm{O}-i-\mathrm{Pr}_{2} \mathrm{O}$ (1:2) (300 ml), and supernatant was removed by decanting. A solution of the residue in ethyl acetate (EtOAc) was washed with $5 \% \mathrm{NaCl}$ aq., and extracted with $0.5 \mathrm{M} \mathrm{HCl}$ aq. The aqueous layer was purified by column chromatography (HP-21, $\mathrm{CH}_{3} \mathrm{CN}-\mathrm{H}_{2} \mathrm{O}$ ), and lyophilized. The residue was solidified from EtOAc to give crude 1 ( $1.91 \mathrm{~g}, 23 \%$ yield). Compound 1 was obtained as a white solid by recrystallization of crude 1 from a mixture of $\mathrm{MeOH}$ and EtOAc. M.p. $183-185^{\circ} \mathrm{C}$ (dec). IR vmax (Nujol) $\mathrm{cm}^{-1} 3358,2758,1773,1753,1720,1663 .{ }^{1} \mathrm{H}$ NMR (DMSO-d $\left.d_{6}\right) \delta 1.15$ (9H, s), 1.0-1.3 (6H, m), 1.4-2.0 (1H, m), $2.91(3 \mathrm{H}, \mathrm{s}), 3.02(3 \mathrm{H}, \mathrm{s}), 4.5-4.8(1 \mathrm{H}, \mathrm{br} \mathrm{t})$, 4.8-5.4 (1H, br), 5.6-6.1 (2H, ABq, $J=5.7 \mathrm{~Hz}), 9.2-10.6$ (2H, br).

1-Ethylpropyloxycarbonyloxymethyl (1R,5S,6S)-2-[(3S,5S)-5-(N,N-Dimethylcarbamoyl)pyrrolidin-3-ylthio]-6-[(1R)-1-hydroxyethyl]-1-methylcarbapen-2-em-3carboxylate Hydrochloride (2). To a suspension of MEPM (2.99 g, $7.80 \mathrm{mmol})$ in DMF $(12 \mathrm{ml})$ at -20 to $-15^{\circ} \mathrm{C}$ were added dropwise a solution of 1-ethylpropyl iodomethyl carbonate $(2.12 \mathrm{~g}, 7.79 \mathrm{mmol})$ in DMF $(3.0 \mathrm{ml})$ and $\mathrm{K}_{2} \mathrm{CO}_{3}(1.29 \mathrm{~g}, 9.36 \mathrm{mmol})$, and the mixture was stirred at the same temperature for $0.5 \mathrm{~h}$. Compound 2 was obtained as a white solid $(700 \mathrm{mg}$, $16 \%$ yield) by a similar procedure to that described in the synthesis of 1 . IR $v \max (\mathrm{Nujol}) \mathrm{cm}^{-1} 3362,1765,1720,1657 .{ }^{1} \mathrm{H} \mathrm{NMR}\left(\mathrm{CDCl}_{3}\right) \delta 0.91,0.92$ (total $6 \mathrm{H}$, each t, $J=7.3 \mathrm{~Hz}), 1.25(3 \mathrm{H}, \mathrm{d}, J=7.1 \mathrm{~Hz}), 1.32(3 \mathrm{H}, \mathrm{d}, J=6.1 \mathrm{~Hz})$, $1.58-1.70(4 \mathrm{H}, \mathrm{m}), 1.60-1.70(1 \mathrm{H}, \mathrm{br}), 1.75-1.86(1 \mathrm{H}, \mathrm{m}), 2.97-3.10(1 \mathrm{H}, \mathrm{m})$, $3.00(3 \mathrm{H}, \quad \mathrm{s}), \quad 3.09(3 \mathrm{H}, \quad \mathrm{s}), \quad 3.26 \quad(1 \mathrm{H}, \quad \mathrm{dd}, \quad J=5.6, \quad 2.4 \mathrm{~Hz})$, 3.35-3.47 $(1 \mathrm{H}, \mathrm{m}), 3.60-3.70(1 \mathrm{H}, \mathrm{m}), 4.08-4.25(2 \mathrm{H}, \mathrm{m}), 4.25-4.34(1 \mathrm{H}$, m), $4.50(1 \mathrm{H}, \mathrm{dd}, J=9.5,2.4 \mathrm{~Hz}), 4.64(1 \mathrm{H}$, quintet, $J=6.1 \mathrm{~Hz}), 5.03(1 \mathrm{H}, \mathrm{t}$, $J=8.6 \mathrm{~Hz}), 5.79(2 \mathrm{H}, \mathrm{q}, J=5.8 \mathrm{~Hz})$.

Sodium (1R,5S,6S)-2-[(3S,5S)-5-(N,N-Dimethylcarbamoyl)-1-(isobutyryloxymethyloxycarbonyl)pyrrolidin-3-ylthio]-6-[(1R)-1-hydroxyethyl]-1-methylcarbapen-2-em-3carboxylate (3). To a solution of isobutyryloxymethyl p-nitrophenyl carbonate $(405 \mathrm{mg}, 1.43 \mathrm{mmol})$ in DMF $(2 \mathrm{ml})$ at $0^{\circ} \mathrm{C}$ was added MEPM $(500 \mathrm{mg}$, $1.30 \mathrm{mmol}$ ), and the mixture was stirred at room temperature for $1 \mathrm{~h}$. The reaction mixture was poured into EtOAc-i- $\mathrm{Pr}_{2} \mathrm{O}(1: 1)(70 \mathrm{ml})$, and left to stand at $0^{\circ} \mathrm{C}$ for $10 \mathrm{~min}$. The formed precipitate was collected by filtration and washed with EtOAc-i- $\operatorname{Pr}_{2} \mathrm{O}$ (1:1). To a solution of the obtained compound in $\mathrm{H}_{2} \mathrm{O}$ (40 ml) was added $\mathrm{NaHCO}_{3}(164 \mathrm{mg}, 1.95 \mathrm{mmol})$ for salting, and the mixture was purified by column chromatography ( $\left.\mathrm{HP}-21, \mathrm{CH}_{3} \mathrm{CN}-\mathrm{H}_{2} \mathrm{O}\right)$, and lyophilized to give 3 (300 mg, $42 \%$ yield) as a solid. IR $v \max$ (Nujol) $\mathrm{cm}^{-1} 3400,1728 .{ }^{1} \mathrm{H}$ NMR $\left(\mathrm{D}_{2} \mathrm{O}\right) \delta 1.14(6 \mathrm{H}, \mathrm{d}, J=6.8 \mathrm{~Hz}), 1.21(3 \mathrm{H}, \mathrm{d}, J=6.1 \mathrm{~Hz}), 1.28(3 \mathrm{H}, \mathrm{d}, J=7.7 \mathrm{~Hz})$, $1.60-2.87 \quad(3 \mathrm{H}, \quad \mathrm{m}), \quad 2.93-3.11 \quad(6 \mathrm{H}, \quad \mathrm{m}), \quad 3.23-4.36 \quad(7 \mathrm{H}, \quad \mathrm{m})$, $4.80-5.01(1 \mathrm{H}, \mathrm{m}), 5.66-5.73(2 \mathrm{H}, \mathrm{m})$.

Pivaloyloxymethyl (1R,5S,6S)-2-[(3S,5S)-5-(N,N-Dimethylcarbamoyl)-1-(isobutyryloxymethyloxycarbonyl)pyrrolidin-3-ylthio]-6-[(1R)-1-hydroxyethyl]-1-methylcarbapen-2-em-3-carboxylate (4). To a suspension of MEPM (17.4 g, $45.5 \mathrm{mmol})$ in DMF $(70 \mathrm{ml})$ at $0{ }^{\circ} \mathrm{C}$ was added isobutyryloxymethyl $p$-nitrophenyl carbonate $(15.0 \mathrm{~g}, 50.1 \mathrm{mmol})$, and the mixture was stirred at room temperature for $1 \mathrm{~h}$, followed by the addition of pivaloyloxymethyl iodide $(30.6 \mathrm{~g}, 114 \mathrm{mmol})$ at $0{ }^{\circ} \mathrm{C}$, and stirring at room temperature for $2 \mathrm{~h}$. After the addition of $5 \% \mathrm{NaHCO}_{3}$ aq. $(150 \mathrm{ml})$, the mixture was extracted with EtOAc $(200 \mathrm{ml})$, and then the organic layer was washed with $5 \% \mathrm{NaHCO}_{3}$ aq. and brine, dried over $\mathrm{Na}_{2} \mathrm{SO}_{4}$, and evaporated under reduced pressure. The residue was purified by column chromatography (silica gel, $n$-hexane-EtOAc) to give a solid $(16.5 \mathrm{~g})$. The solid was recrystallized from EtOAc- $i-\mathrm{Pr}_{2} \mathrm{O}(2: 3)(200 \mathrm{ml})$ to give $4\left(12.0 \mathrm{~g}, 41 \%\right.$ yield) as a white solid. M.p. $139-141{ }^{\circ} \mathrm{C}$. IR $v \max$ (Nujol) $\mathrm{cm}^{-1} 3385,1796,1755,1728,1636 .{ }^{1} \mathrm{H}$ NMR $\left(\mathrm{CDCl}_{3}\right) \delta 1.18(6 \mathrm{H}, \mathrm{d}$, $J=7.5 \mathrm{~Hz}), 1.22(9 \mathrm{H}, \mathrm{s}), 1.26(3 \mathrm{H}, \mathrm{d}, J=7.3 \mathrm{~Hz}), 1.34(3 \mathrm{H}, \mathrm{d}, J=6.4 \mathrm{~Hz}), 1.7-$ $2.8(4 \mathrm{H}, \mathrm{m}), 2.95,2.97$ (total $3 \mathrm{H}$, each s), 3.07, 3.11 (total $3 \mathrm{H}$, each s), 3.1-3.9 $(4 \mathrm{H}, \mathrm{m}), 3.9-4.4(3 \mathrm{H}, \mathrm{m}), 4.71(1 \mathrm{H}, \mathrm{m}), 5.6-5.8(2 \mathrm{H}, \mathrm{m}), 5.88(2 \mathrm{H}, \mathrm{ABq}$, $J=6.1 \mathrm{~Hz})$. MS m/z $643(\mathrm{M}+\mathrm{H})^{+}$. Anal Calc for $\mathrm{C}_{29} \mathrm{H}_{43} \mathrm{~N}_{3} \mathrm{O}_{11} \mathrm{~S}$ : C $54.28, \mathrm{H}$ 6.75, N 6.55. Found: C 54.27, H 6.48, N 6.55 .

Compounds 5-10 were prepared according to the procedure for 4 .

Pivaloyloxymethyl (1R,5S,6S)-2-[(3S,5S)-5-(N,N-Dimethylcarbamoyl)-1-(propionyloxymethyloxycarbonyl)pyrrolidin-3-ylthio]-6-[(1R)-1-hydroxyethyl]-1-methylcarbapen-2-em-3-carboxylate (5). Yield $28 \%$. M.p. $75-77^{\circ} \mathrm{C}$. IR vmax (Nujol) $\mathrm{cm}^{-1} 3436,1759,1724,1649 .{ }^{1} \mathrm{H}$ NMR $\left(\mathrm{CDCl}_{3}\right) \delta 1.14(3 \mathrm{H}, \mathrm{t}, J=7.7 \mathrm{~Hz}), 1.22$ $(9 \mathrm{H}, \mathrm{s}), 1.26(3 \mathrm{H}, \mathrm{d}, J=7.1 \mathrm{~Hz}), 1.32(3 \mathrm{H}, \mathrm{d}, J=6.1 \mathrm{~Hz}), 1.7-2.1,2.4-2.8$ (total $2 \mathrm{H}, \mathrm{m}), 2.38(2 \mathrm{H}, \mathrm{q}, J=7.7 \mathrm{~Hz}), 2.95,2.98$ (total $3 \mathrm{H}$, each s), 3.07, 3.11 (total $3 \mathrm{H}$, each s), 3.1-3.8 $(4 \mathrm{H}, \mathrm{m}), 3.9-4.3(3 \mathrm{H}, \mathrm{m}), 4.73(1 \mathrm{H}, \mathrm{m}), 5.6-5.8(2 \mathrm{H}, \mathrm{m})$, $5.88(2 \mathrm{H}, \quad \mathrm{ABq}, \quad J=6.1 \mathrm{~Hz})$. MS $\mathrm{m} / \mathrm{z} 643(\mathrm{M}+\mathrm{H})^{+}$. Anal. Calc for $\mathrm{C}_{28} \mathrm{H}_{41} \mathrm{~N}_{3} \mathrm{O}_{11} \mathrm{~S} \cdot \mathrm{H}_{2} \mathrm{O}$ : C 52.08, H 6.71, N 6.51. Found: C 51.83, H 6.32, N 6.36.

Pivaloyloxymethyl (1R,5S,6S)-2-[(3S,5S)-1-(Butyryloxymethyloxycarbonyl)-5-(N, N-dimethylcarbamoyl)-pyrrolidin-3-ylthio]-6-[(1R)-1-hydroxyethyl]-1-methylcarbapen-2-em-3-carboxylate (6). Yield 51\%. M.p. $134-136^{\circ} \mathrm{C}$. IR vmax (Nujol) $\mathrm{cm}^{-1} 3395,1794,1753,1728,1636 .{ }^{1} \mathrm{H} \mathrm{NMR}\left(\mathrm{CDCl}_{3}\right) \delta 0.94(3 \mathrm{H}, \mathrm{t}, J=7.2 \mathrm{~Hz})$, $1.22(9 \mathrm{H}, \mathrm{s}), 1.26(3 \mathrm{H}, \mathrm{d}, J=7.3 \mathrm{~Hz}), 1.33(3 \mathrm{H}, \mathrm{d}, J=6.1 \mathrm{~Hz}), 1.65(2 \mathrm{H}, \mathrm{m}), 2.34$ $(2 \mathrm{H}, \mathrm{t}, J=7.2 \mathrm{~Hz}), 1.70-2.80(3 \mathrm{H}, \mathrm{m}), 2.90-3.20(6 \mathrm{H}, \mathrm{m}), 3.10-3.90(4 \mathrm{H}, \mathrm{m})$, $3.90-4.40(3 \mathrm{H}, \mathrm{m}), 4.71(1 \mathrm{H}, \mathrm{m}), 5.60-5.80(2 \mathrm{H}, \mathrm{m}), 5.89(2 \mathrm{H}, \mathrm{q}, J=6.4 \mathrm{~Hz})$. MS m/z $643(\mathrm{M}+\mathrm{H})^{+}$. Anal Calc for $\mathrm{C}_{29} \mathrm{H}_{43} \mathrm{~N}_{3} \mathrm{O}_{11} \mathrm{~S}$ : C 54.28, H 6.75, N 6.55. Found: C 54.33, H 6.79, N 6.53 .

Pivaloyloxymethyl (1R,5S,6S)-2-[(3S,5S)-5-(N,N-Dimethylcarbamoyl)-1-(valeryloxymethyloxycarbonyl)pyrrolidin-3-ylthio]-6-[(1R)-1-hydroxyethyl]-1-methylcarbapen-2-em-3-carboxylate (7). Yield $37 \%$. M.p. $90-92{ }^{\circ} \mathrm{C}$. IR vmax (Nujol) $\mathrm{cm}^{-1} 3395,1755,1709,1647 .{ }^{1} \mathrm{H} \mathrm{NMR}\left(\mathrm{CDCl}_{3}\right) \delta 0.91(3 \mathrm{H}, \mathrm{t}, J=7.3 \mathrm{~Hz}), 1.22$ $(9 \mathrm{H}, \mathrm{s}), 1.26,1.27$ (total $3 \mathrm{H}$, each d, $J=7.1 \mathrm{~Hz}$ ) $1.34,1.35$ (total $3 \mathrm{H}$, each d, $J=5.8 \mathrm{~Hz}), 1.20-1.40(2 \mathrm{H}, \mathrm{m}), 1.55-1.70(2 \mathrm{H}, \mathrm{m}), 1.88-1.99(1 \mathrm{H}, \mathrm{m}), 2.33-$ $2.40(2 \mathrm{H}, \mathrm{m}), 2.63-2.73(1 \mathrm{H}, \mathrm{m}), 2.95,2.98$ (total $3 \mathrm{H}$, each s), 3.07, 3.11 (total $3 \mathrm{H}$, each s), 3.22, 3.24 (total $1 \mathrm{H}$, each $\mathrm{dd}, J=7.1,2.7 \mathrm{~Hz}$ ), $3.32-3.42$ $(1 \mathrm{H}, \mathrm{m}), 3.43,3.45$ (total $1 \mathrm{H}$, each dd, $J=10.5,1.4 \mathrm{~Hz}), 3.55-3.68(1 \mathrm{H}, \mathrm{m})$, $4.04,4.13$ (total $1 \mathrm{H}$, each $\mathrm{dd}, J=10.5,7.3 \mathrm{~Hz}$ ), 4.22, 4.26 (total $1 \mathrm{H}$, each dd, $J=9.5,2.7 \mathrm{~Hz}), 4.20-4.28(1 \mathrm{H}, \mathrm{m}), 4.69,4.75($ total $1 \mathrm{H}$, each $\mathrm{t}, J=8.2,8.1 \mathrm{~Hz})$, 5.64, 5.68 (total $1 \mathrm{H}$, each $\mathrm{ABq}, J=5.8 \mathrm{~Hz}$ ), 5.68, 5.79 (total $1 \mathrm{H}$, each $\mathrm{ABq}$, $J=5.6 \mathrm{~Hz}), 5.83,5.94($ total $2 \mathrm{H}$, each $\mathrm{ABq}, J=5.4 \mathrm{~Hz})$. MS m/z $657(\mathrm{M}+\mathrm{H})^{+}$. Anal Calc for $\mathrm{C}_{30} \mathrm{H}_{45} \mathrm{~N}_{3} \mathrm{O}_{11} \mathrm{~S} \cdot 0.5 \mathrm{H}_{2} \mathrm{O}$ : C $54.20, \mathrm{H} 6.97, \mathrm{~N}$ 6.32. Found: C 54.08, H 6.81, N 6.24.

1-Ethylpropyloxycarbonyloxymethyl (1R,5S,6S)-2-[(3S,5S)-5-(N,N-Dimethylcarbamoyl)-1-(isobutyryloxymethyloxycarbonyl)pyrrolidin-3-ylthio]-6-[(1R)-1-hydroxyethyl]-1-methylcarbapen-2-em-3-carboxylate (8). Yield 70\%. M.p. 108$110^{\circ} \mathrm{C}$. IR vmax (Nujol) $\mathrm{cm}^{-1} 3395,1759,1724,1651 .{ }^{1} \mathrm{H}$ NMR $\left(\mathrm{CDCl}_{3}\right) \delta$ $0.91(6 \mathrm{H}, \mathrm{t}, J=7.3 \mathrm{~Hz}), 1.17(6 \mathrm{H}, \mathrm{d}, J=7.0 \mathrm{~Hz}), 1.25(3 \mathrm{H}, \mathrm{d}, J=7.3 \mathrm{~Hz}), 1.33$ $(3 \mathrm{H}, \mathrm{d}, J=6.1 \mathrm{~Hz}), 1.50-2.80(8 \mathrm{H}, \mathrm{m}), 2.95,2.97$ (total $3 \mathrm{H}$, each s), 3.07, 3.11 (total $3 \mathrm{H}$, each s), 3.10-3.90 (4H, m), 3.90-4.40 (3H, m), 4.50-4.80 (2H, m), $5.60-6.00(4 \mathrm{H}, \mathrm{m}) . \mathrm{MS} \mathrm{m} / \mathrm{z} 673(\mathrm{M}+\mathrm{H})^{+}$. Anal Calc for $\mathrm{C}_{30} \mathrm{H}_{45} \mathrm{~N}_{3} \mathrm{O}_{12} \mathrm{~S}: \mathrm{C}$ 53.64, H 6.75, N 6.26. Found: C 53.57, H 6.72, N 6.22.

1-(Cyclohexyloxycarbonyloxy)ethyl (1R,5S,6S)-2-[(3S,5S)-5-(N,N-Dimethylcarbamoyl)-1-(isobutyryloxymethyloxycarbonyl)pyrrolidin-3-ylthio]-6-[(1R)-1-hydroxyethyl]-1-methylcarbapen-2-em-3-carboxylate (9). Yield 39\%. M.p. $85-86^{\circ} \mathrm{C}$. IR vmax (Nujol) $\mathrm{cm}^{-1} 3395,1749,1717,1653 .{ }^{1} \mathrm{H}$ NMR $\left(\mathrm{CDCl}_{3}\right) \delta 1.18(6 \mathrm{H}, \mathrm{d}$, $J=7.0 \mathrm{~Hz}), 1.26(3 \mathrm{H}, \mathrm{d}, J=7.0 \mathrm{~Hz}), 1.33(3 \mathrm{H}, \mathrm{d}, J=6.4 \mathrm{~Hz}), 1.10-2.40(12 \mathrm{H}, \mathrm{m})$, $1.58,1.60$ (total $3 \mathrm{H}$, each d, $J=5.5 \mathrm{~Hz}), 2.40-2.90(2 \mathrm{H}, \mathrm{m}), 2.95,2.97$ (total $3 \mathrm{H}$, each s), 3.06, 3.10 (total $3 \mathrm{H}$, each s), 3.10-3.90 $(4 \mathrm{H}, \mathrm{m}), 3.90-4.40(3 \mathrm{H}, \mathrm{m})$, 4.60-5.10 (2H, m), 5.60-5.80 (2H, m), $6.87(1 \mathrm{H}, \mathrm{q}, J=5.5 \mathrm{~Hz}) . \mathrm{MS} \mathrm{m} / \mathrm{z} 699$ $(\mathrm{M}+\mathrm{H})^{+}$. Anal Calc for $\mathrm{C}_{32} \mathrm{H}_{47} \mathrm{~N}_{3} \mathrm{O}_{12} \mathrm{~S} \cdot \mathrm{H}_{2} \mathrm{O}: \mathrm{C} 53.69, \mathrm{H}$ 6.90, N 5.87. Found: C 53.63, H 6.70, N 5.79 .

1-(Isopropyloxycarbonyloxy)ethyl (1R,5S,6S)-2-[(3S,5S)-5-(N,N-Dimethylcarbamoyl)1-(isobutyryloxymethyloxycarbonyl)pyrrolidin-3-ylthio]-6-[(1R)-1-hydroxyethyl]-1methylcarbapen-2-em-3-carboxylate (10). Yield 48\%. M.p. 76-78 ${ }^{\circ} \mathrm{C}$. IR vmax (Nujol) $\mathrm{cm}^{-1} 3234,1749,1716,1645 .{ }^{1} \mathrm{H}$ NMR $\left(\mathrm{CDCl}_{3}\right) \delta 1.14-1.22(6 \mathrm{H}, \mathrm{m})$, $1.23-1.38(12 \mathrm{H}, \mathrm{m}), 1.56-1.62(3 \mathrm{H}, \mathrm{m}), 1.88-2.10(2 \mathrm{H}, \mathrm{m}), 2.54-2.73(2 \mathrm{H}, \mathrm{m})$, 2.95, 2.98 (total $3 \mathrm{H}$, each s), 3.07, 3.11 (total $3 \mathrm{H}$, each s), 3.30-3.49 (2H, m), 3.54-3.70 (1H, m), 4.00-4.15 (1H, m), 4.17-4.27 (2H, m), 4.69, 4.74 (total $1 \mathrm{H}$, each t, $J=8.0 \mathrm{~Hz}), 4.85-4.95(1 \mathrm{H}, \mathrm{m}), 5.63-5.82(2 \mathrm{H}, \mathrm{m}), 6.83-6.90(1 \mathrm{H}, \mathrm{m})$. MS m/z $659(\mathrm{M}+\mathrm{H})^{+}$. Anal Calc for $\mathrm{C}_{29} \mathrm{H}_{43} \mathrm{~N}_{3} \mathrm{O}_{12} \mathrm{~S} \cdot 1.5 \mathrm{H}_{2} \mathrm{O}$ : C 50.87, H 6.77, N 6.14. Found: C 50.90, H 6.52, N 6.08 . 


\section{Synthetic procedures in Scheme 2}

p-Nitrobenzyl (1R,5S,6S)-2-[(3S,5S)-5-(N,N-Dimethylcarbamoyl)-1-(isobutyryloxymethyloxycarbonyl)pyrrolidin-3-ylthio]-6-[(1R)-1-hydroxyethyl]-1-methylcarbapen-2-em-3-carboxylate (11). To a solution of BMP $(9.64 \mathrm{~g}, 30.3 \mathrm{mmol})$ in $\mathrm{CH}_{3} \mathrm{CN}(150 \mathrm{ml})$ at $5{ }^{\circ} \mathrm{C}$ were added MAP $(15.0 \mathrm{~g}, 25.2 \mathrm{mmol})$ and $i-\mathrm{Pr}_{2} \mathrm{NEt}$ $(6.0 \mathrm{ml}, 35 \mathrm{mmol})$, and the mixture was stirred at the same temperature for $2 \mathrm{~h}$ under $\mathrm{Ar}$ atmosphere. After evaporation of the mixture under reduced pressure, a solution of the residue in EtOAc was washed with $10 \%$ citric acid aq., $5 \% \mathrm{NaHCO}_{3}$ aq. and $5 \% \mathrm{NaCl}$ aq., dried over $\mathrm{Na}_{2} \mathrm{SO}_{4}$, and evaporated under reduced pressure. A solution of the residue in a mixture of EtOAc-i- $\mathrm{Pr}_{2} \mathrm{O}$ $(1: 1)(150 \mathrm{ml})$ was stirred at room temperature overnight, and the resulting precipitate was collected by filtration to give 11 ( $15.4 \mathrm{~g}, 92 \%$ yield) as a solid. IR $v \max (\mathrm{ATR}) \mathrm{cm}^{-1} 3430,1766,1732,1705,1655 .{ }^{1} \mathrm{H}$ NMR $\left(\mathrm{CDCl}_{3}\right) \delta 1.15-1.20$ $(6 \mathrm{H}, \mathrm{m}), 1.27,1.29$ (total $3 \mathrm{H}$, each $\mathrm{d}, J=6.1 \mathrm{~Hz}, 7.1 \mathrm{~Hz}$ ) , 1.37, 1.38 (total $3 \mathrm{H}$, each $\mathrm{d}, J=5.6,6.1 \mathrm{~Hz}), 1.88-2.00(1 \mathrm{H}, \mathrm{m}), 2.53-2.65(1 \mathrm{H}, \mathrm{m}), 2.63-2.73(1 \mathrm{H}$, $\mathrm{m}), 2.95,2.98$ (total $3 \mathrm{H}$, each s), 3.06, 3.11 (total $1 \mathrm{H}$, each s), 3.26, 3.28 (total $1 \mathrm{H}$, each dd, $J=7.1,2.5 \mathrm{~Hz}$ ), 3.32-3.43 $(1 \mathrm{H}, \mathrm{m}), 3.45,3.48$ (total $1 \mathrm{H}$, each d, $J=10.5 \mathrm{~Hz}), 3.57-3.68(1 \mathrm{H}, \mathrm{m}), 4.05,4.14($ total $1 \mathrm{H}$, each dd, $J=10.5,7.1 \mathrm{~Hz})$, $4.25,4.28$ (total $1 \mathrm{H}$, each dd, $J=9.5,2.5 \mathrm{~Hz}), 4.25-4.32(1 \mathrm{H}, \mathrm{m}), 4.69,4.74$ (total $1 \mathrm{H}$, each t, $J=8.1 \mathrm{~Hz}$ ), 5.24, 5.25 (total $1 \mathrm{H}$, each d, $J=13.7 \mathrm{~Hz}), 5.49(1 \mathrm{H}$, d, $J=13.7 \mathrm{~Hz}$ ), 5.65, 5.68 (total $1 \mathrm{H}$, each d, $J=5.6 \mathrm{~Hz}$ ), 5.69, 5.80 (total $1 \mathrm{H}$, each d, $J=5.6 \mathrm{~Hz}), 7.60-7.70(2 \mathrm{H}, \mathrm{m}), 8.15-8.25(2 \mathrm{H}, \mathrm{m})$.

Pivaloyloxymethyl (1R,5S,6S)-2-[(3S,5S)-5-(N,N-Dimethylcarbamoyl)-1-(isobutyryloxymethyloxycarbonyl)pyrrolidin-3-ylthio]-6-[(1R)-1-hydroxyethyl]-1-methylcarbapen-2-em-3-carboxylate (4). A solution of $11(1.00 \mathrm{~g}, 1.51 \mathrm{mmol})$ in THF-0.1 M MOPS buffer ( $\mathrm{pH}$ 7.0) (1:1) (100 ml) was hydrogenated at $3 \mathrm{~kg} \mathrm{~cm}^{-2}$ in the presence of $10 \%$ Pd-C $(250 \mathrm{mg})$ at $35^{\circ} \mathrm{C}$ for $1 \mathrm{~h}$. After removal of the catalyst by filtration, the filtrate was extracted with $0.1 \mathrm{M}$ MOPS buffer $(\mathrm{pH} 7.0)(30 \mathrm{ml})$, and then, THF was evaporated under reduced pressure. The aqueous residue was washed with EtOAc, and evaporated under reduced pressure. To a solution of the residue in $\mathrm{CH}_{2} \mathrm{Cl}_{2}(10 \mathrm{ml})$ were added BTEAC $(100 \mathrm{mg}, 0.44 \mathrm{mmol})$ and pivaloyloxymethyl iodide $(548 \mathrm{mg}$, $2.26 \mathrm{mmol}$ ), and the mixture was stirred at room temperature overnight. After evaporation of the mixture under reduced pressure, the solution of the residue in EtOAc $(100 \mathrm{ml})$ was washed with water $(50 \mathrm{ml})$ and $5 \% \mathrm{NaCl}$ aq., dried over $\mathrm{Na}_{2} \mathrm{SO}_{4}$, and evaporated under reduced pressure. The residue was purified by column chromatography (silica gel, EtOAc-acetone) to give an oil $(1.1 \mathrm{~g})$. To the solution of the oil in EtOAc $(2.2 \mathrm{ml})$ was added $i-\mathrm{Pr}_{2} \mathrm{O}(5.0 \mathrm{ml})$, and the mixture was stirred at room temperature overnight. The resulting precipitate was collected by filtration to give $\mathbf{4}$ ( $803 \mathrm{mg}, 83 \%$ yield) as a white solid.

1-Ethylpropyloxycarbonyloxymethyl (1R,5S,6S)-2-[(3S,5S)-5-(N,N-Dimethylcarbamoyl)-1-(isobutyryloxymethyloxycarbonyl)pyrrolidin-3-ylthio]-6-[(1R)-1-hydroxyethyl]-1-methylcarbapen-2-em-3-carboxylate (8). Compound 8 was obtained as a white solid $(833 \mathrm{mg}, 82 \%$ yield) from $11(1.00 \mathrm{~g}, 1.51 \mathrm{mmol})$ in a similar manner to that described in the synthesis of 4 .

\section{Synthetic procedures in Scheme 3}

Pivaloyloxymethyl (4R)-4\{(2R,3S)-3-[(1R)-1-(tert-Butyldimethylsilyloxy)ethyl]4-oxoazetidin-2-y\}-3-oxopentanoate (12). To a suspension of $\beta$-MAC (5.70 g, $18.9 \mathrm{mmol})$ in $\mathrm{CH}_{3} \mathrm{CN}(57 \mathrm{ml})$ was added $\mathrm{CDI}(3.37 \mathrm{~g}, 20.8 \mathrm{mmol})$, and the mixture was stirred at room temperature for $1.5 \mathrm{~h}$. The mixture was poured into magnesium bis(pivaloyloxymethyloxycarbonylacetate) ( $15.8 \mathrm{~g}, 34.4 \mathrm{mmol}$ ), and the mixture was stirred at room temperature for $1.5 \mathrm{~h}$, at $30-40{ }^{\circ} \mathrm{C}$ for $1.5 \mathrm{~h}$, and then evaporated under reduced pressure. A solution of the residue in EtOAc was washed with water and brine, dried over $\mathrm{Na}_{2} \mathrm{SO}_{4}$, and evaporated under reduced pressure. The residue was purified by column chromatography (silica gel, $n$-hexane-EtOAc) to give $\mathbf{1 2}\left(1.02 \mathrm{~g}, 12 \%\right.$ yield) as an oil. ${ }^{1} \mathrm{H}$ NMR $\left(\mathrm{CDCl}_{3}\right) \quad \delta \quad 0.06,0.07$ (total $\left.6 \mathrm{H}, \mathrm{s}\right), 0.87(9 \mathrm{H}, \mathrm{s}), 1.13,1.15$ (total $3 \mathrm{H}$, each t, $J=6.3 \mathrm{~Hz}), 1.18-1.25(3 \mathrm{H}, \mathrm{m}), 1.22(9 \mathrm{H}, \mathrm{s}), 2.38-2.47,2.88-2.98$ (total $1 \mathrm{H}$, each $\mathrm{m}), 2.87-2.95(1 \mathrm{H}, \mathrm{m}), 3.57(1.2 \mathrm{H}, \mathrm{s}), 3.82(0.4 \mathrm{H}$, dd, $J=6.6$, $2.2 \mathrm{~Hz}), 3.95(0.6 \mathrm{H}, \mathrm{dd}, J=4.4,2.2 \mathrm{~Hz}), 4.15-4.22(1 \mathrm{H}, \mathrm{m}), 5.09(0.4 \mathrm{H}, \mathrm{s}), 5.76$, 5.78 (total $1.2 \mathrm{H}$, each q, $J=5.6 \mathrm{~Hz}$ ), $5.81(0.8 \mathrm{H}, \mathrm{s}), 5.90,5.91$ (total $1 \mathrm{H}$, each br s), $11.84(0.4 \mathrm{H}, \mathrm{s})$.
Pivaloyloxymethyl (4R)-4\{(2R,3S)-3-[(1R)-1-(tert-Butyldimethylsilyloxy)ethyl]-4oxoazetidin-2-y\}-2-diaza-3-oxo-pentanoate (13). To a solution of $12(500 \mathrm{mg}$, $1.09 \mathrm{mmol})$ in $\mathrm{CH}_{3} \mathrm{CN}(10 \mathrm{ml})$ at $0^{\circ} \mathrm{C}$ were added $p$-dodecylbenzenesulfonyl azide $(461 \mathrm{mg}, 1.31 \mathrm{mmol})$ and $\mathrm{Et}_{3} \mathrm{~N}(0.18 \mathrm{ml}, 1.29 \mathrm{mmol})$, and the mixture was stirred at the same temperature for $30 \mathrm{~min}$. The mixture was evaporated under reduced pressure, and the residue was purified by column chromatography (silica gel, $n$-hexane-EtOAc) to give $\mathbf{1 3}$ (450 mg, 85\% yield) as an oil. ${ }^{1} \mathrm{H} \mathrm{NMR}\left(\mathrm{CDCl}_{3}\right)$ $\delta 0.06,0.07$ (total $6 \mathrm{H}$, each s), $0.86(9 \mathrm{H}, \mathrm{s}), 1.18(3 \mathrm{H}, \mathrm{d}, J=6.8 \mathrm{~Hz}), 1.19(3 \mathrm{H}, \mathrm{d}$, $J=6.4 \mathrm{~Hz}), 1.23(9 \mathrm{H}, \mathrm{s}), 2.96(1 \mathrm{H}, \mathrm{dd}, J=4.4,1.4 \mathrm{~Hz}), 3.85-3.92(2 \mathrm{H}, \mathrm{m})$, $4.14-4.22(1 \mathrm{H}, \mathrm{m}), 5.87(2 \mathrm{H}, \mathrm{s}), 5.90(1 \mathrm{H}, \mathrm{br} \mathrm{s})$.

Pivaloyloxymethyl (1R,5R,6S)-6-[(1R)-1-(tert-Butyldimethylsilyloxy)ethyl]-2(diphenylphosphoryloxy)-1-methylcarbapen-2-em-3-carboxylate (14). To a solution of $13(440 \mathrm{mg}, 0.91 \mathrm{mmol})$ in EtOAc $(3.5 \mathrm{ml})$ at $50^{\circ} \mathrm{C}$ was added $\left[(\mathrm{AcO})_{2} \mathrm{Rh}\right]_{2} \cdot 2 \mathrm{H}_{2} \mathrm{O}(22 \mathrm{mg}, 0.05 \mathrm{mmol})$, and the mixture was stirred for $20 \mathrm{~min}$, and then evaporated under reduced pressure. To a solution of the residue in $\mathrm{CH}_{3} \mathrm{CN}(4 \mathrm{ml})$ at $0{ }^{\circ} \mathrm{C}$ were added diphenyl chlorophosphate $(0.21 \mathrm{ml}, 1.0 \mathrm{mmol})$ and $i-\operatorname{Pr}_{2} \mathrm{NEt}(0.17 \mathrm{ml}, 0.98 \mathrm{mmol})$, and then the mixture was stirred at the same temperature for $40 \mathrm{~min}$. After the addition of EtOAc, the mixture was washed with water and brine, dried over $\mathrm{Na}_{2} \mathrm{SO}_{4}$, and evaporated under reduced pressure. The residue was purified by column chromatography (silica gel, $n$-hexane-EtOAc) to give $\mathbf{1 4}(480 \mathrm{mg}, 77 \%$ yield) as an oil. ${ }^{1} \mathrm{H}$ NMR $\left(\mathrm{CDCl}_{3}\right) \delta 0.06,0.07$ (total $6 \mathrm{H}$, each s), $0.86(9 \mathrm{H}, \mathrm{s}), 1.18$ $(3 \mathrm{H}, \mathrm{d}, J=5.8 \mathrm{~Hz}), 1.19(9 \mathrm{H}, \mathrm{s}), 1.22(3 \mathrm{H}, \mathrm{d}, J=8.0 \mathrm{~Hz}), 3.23(1 \mathrm{H}, \mathrm{dd}, J=6.1$, $2.9 \mathrm{~Hz}), 3.38-3.49(1 \mathrm{H}, \mathrm{m}), 4.13(1 \mathrm{H}, \mathrm{dd}, J=10.2,2.9 \mathrm{~Hz}), 4.15-4.23(1 \mathrm{H}, \mathrm{m})$, 5.78, 5.80 (total $2 \mathrm{H}$, each $\mathrm{ABq}, J=5.4 \mathrm{~Hz}), 7.19-7.43(10 \mathrm{H}, \mathrm{m})$.

Pivaloyloxymethyl (1R,5S,6S)-6-[(1R)-1-(tert-Butyldimethylsilyloxy)ethyl]-2-[(3S, 5S)-5-(N,N-dimethylcarbamoyl)-1-(isobutyryloxymethyloxycarbonyl)pyrrolidin-3ylthio]-1-methylcarbapen-2-em-3-carboxylate (15). Compound 15 was obtained as an oil $(230 \mathrm{mg}, 43 \%$ yield) from $14(480 \mathrm{mg}, 0.70 \mathrm{mmol})$ in a similar manner as described in the synthesis of 11 in Scheme 2. ${ }^{1} \mathrm{H}$ NMR $\left(\mathrm{CDCl}_{3}\right) \delta 0.08(6 \mathrm{H}, \mathrm{s})$, 0.89 (9H, s), $1.14-1.29(12 \mathrm{H}, \mathrm{m}), 1.22(9 \mathrm{H}, \mathrm{s}), 1.86-1.99(1 \mathrm{H}, \mathrm{m}), 2.53-2.63$ $(1 \mathrm{H}, \mathrm{m}), 2.63-2.73(1 \mathrm{H}, \mathrm{m}), 2.95,2.98$ (total $3 \mathrm{H}$, each s), 3.06, 3.11 (total $3 \mathrm{H}$, each s), 3.19, 3.21 (total $1 \mathrm{H}$, each dd, $J=6.1,2.7 \mathrm{~Hz}), 3.24-3.34(1 \mathrm{H}, \mathrm{m}), 3.44$, 3.46 (total $1 \mathrm{H}$, each dd, $J=11.0,3.4 \mathrm{~Hz}), 3.55-3.69(1 \mathrm{H}, \mathrm{m}), 3.99-4.15(1 \mathrm{H}, \mathrm{m})$, 4.18-4.27 $(2 \mathrm{H}, \mathrm{m}), 4.68,4.74$ (total $1 \mathrm{H}$, each $\mathrm{t}, J=8.1,8.1 \mathrm{~Hz}$ ), 5.66, 5.69 (total $1 \mathrm{H}$, each $\mathrm{ABq}, J=5.8 \mathrm{~Hz}$ ), $5.68,5.81$ (total $1 \mathrm{H}$, each $\mathrm{ABq}, J=5.6 \mathrm{~Hz}$ ), $5.83,5.92$ (total $2 \mathrm{H}$, each $\mathrm{ABq}, J=5.4 \mathrm{~Hz}$ ).

Pivaloyloxymethyl (1R,5S,6S)-2-[(3S,5S)-5-(N,N-Dimethylcarbamoyl)-1-(isobutyryloxymethyloxycarbonyl)pyrrolidin-3-ylthio]-6-[(1R)-1-hydroxyethyl]-1-methylcarbapen-2-em-3-carboxylate (4). To a solution of $\mathbf{1 5}(70 \mathrm{mg}, 0.093 \mathrm{mmol})$ in DMF $(0.7 \mathrm{ml})$ was added $\mathrm{Et}_{3} \mathrm{~N} \cdot 3 \mathrm{HF}(30 \mathrm{mg}, 0.9 \mathrm{mmol})$, and the mixture was stirred at room temperature for $23 \mathrm{~h}$. After the addition of EtOAc, the mixture was washed with $5 \% \mathrm{NaCl}$ aq. and brine, dried over $\mathrm{Na}_{2} \mathrm{SO}_{4}$, and evaporated under reduced pressure. To a solution of the residue in EtOAc $(0.5 \mathrm{ml})$ at $0{ }^{\circ} \mathrm{C}$ was added $i-\operatorname{Pr}_{2} \mathrm{O}(1.0 \mathrm{ml})$, and the mixture was stirred for $2 \mathrm{~h}$. The resulting precipitate was collected by filtration to give 4 (10 mg, 17\% yield) as a white solid.

\section{Synthetic Procedures in Scheme 4}

(3S,4S)-3-[(R)-1-(tert-Butyldimethylsilyloxy)ethyl]-4-[(1R)-1\{[(3S,5S)-5-(N,Ndimethylcarbamoyl)-1-(isobutyryloxymethyloxycarbonyl)pyrrolidin-3-ylthio]carbony\}ethyl]-2-azetidinone (16). To a solution of $\beta$-MAC $(5.03 \mathrm{~g}, 16.7 \mathrm{mmol})$ and BMP $(6.38 \mathrm{~g}, 20.0 \mathrm{mmol})$ in DMF $(25 \mathrm{ml})$ at $0{ }^{\circ} \mathrm{C}$ were added EDC $(6.40 \mathrm{~g}$, $33.4 \mathrm{mmol})$ and $N$-methylmorpholine $(3.67 \mathrm{ml}, 33.4 \mathrm{mmol})$ at $0^{\circ} \mathrm{C}$, and the mixture was stirred at room temperature for $1 \mathrm{~h}$. After the addition of EtOAc, the mixture was washed with water and brine, dried over $\mathrm{Na}_{2} \mathrm{SO}_{4}$, and evaporated under reduced pressure. The residue was purified by column chromatography (silica gel, $n$-hexane-EtOAc) to give $\mathbf{1 6}(7.18 \mathrm{~g}, 71 \%$ yield) as an oil. ${ }^{1} \mathrm{H} \mathrm{NMR}\left(\mathrm{CDCl}_{3}\right) \delta 0.06,0.07$ (total $6 \mathrm{H}$, each s), $0.87(9 \mathrm{H}, \mathrm{s}), 1.15$, 1.17 (total $3 \mathrm{H}$, each d, $J=6.3,7.1 \mathrm{~Hz}), 1.18(6 \mathrm{H}, \mathrm{d}, J=7.1 \mathrm{~Hz}), 1.24(3 \mathrm{H}, \mathrm{d}$, $J=7.1 \mathrm{~Hz}), 1.91(1 \mathrm{H}$, ddd, $J=13.2,9.5,7.1 \mathrm{~Hz}), 2.53-2.65(1 \mathrm{H}, \mathrm{m}), 2.84-2.91$ $(1 \mathrm{H}, \mathrm{m}), 2.95,2.98$ (total $3 \mathrm{H}$, each s), 3.06, 3.11 (total $3 \mathrm{H}$, each s), 3.42, 3.46 (total $1 \mathrm{H}$, each dd, $J=10.7,9.0 \mathrm{~Hz}), 3.81-3.86(1 \mathrm{H}, \mathrm{m}), 3.88-4.02(1 \mathrm{H}, \mathrm{m}), 4.07$ $(0.5 \mathrm{H}, \mathrm{dd}, J=10.7,7.8 \mathrm{~Hz}), 4.10(0.5 \mathrm{H}, \mathrm{dd}, J=10.7,7.6 \mathrm{~Hz}), 4.13-4.22(1 \mathrm{H}, \mathrm{m})$, 
4.68, 4.75 (total $1 \mathrm{H}$, each dd, $J=8.0,7.1 \mathrm{~Hz}$ ), 5.66, 5.69 (total $1 \mathrm{H}$, each $\mathrm{ABq}$, $J=5.6 \mathrm{~Hz}), 5.68,5.80($ total $1 \mathrm{H}$, each $\mathrm{ABq}, J=5.6 \mathrm{~Hz}), 5.91(1 \mathrm{H}, \mathrm{s})$.

(3S,4S)-3-[(R)-1-(tert-Butyldimethylsilyloxy)ethyl]-4-[(1R)-1\{[(3S,5S)-5-(N,Ndimethylcarbamoyl)-1-(isobutyryloxymethyloxycarbonyl)pyrrolidin-3-ylthio]carbony\}ethyl]-1-(1-ethylpropyloxycarbonyloxymethyloxyoxalyl)-2-azetidinone (17). To a solution of $16(1.50 \mathrm{~g}, 2.49 \mathrm{mmol})$ in $\mathrm{CH}_{2} \mathrm{Cl}_{2}(15 \mathrm{ml})$ at $-10^{\circ} \mathrm{C}$ were added $\mathrm{Et}_{3} \mathrm{~N}(0.95 \mathrm{ml}, 6.8 \mathrm{mmol})$ and 1-ethylpropyloxycarbonyloxymethyloxyoxalyl chloride $(1.57 \mathrm{~g}, 6.23 \mathrm{mmol})$ in $\mathrm{CH}_{2} \mathrm{Cl}_{2}(15 \mathrm{ml})$, and the mixture was stirred at $0{ }^{\circ} \mathrm{C}$ for $1 \mathrm{~h}$. After the addition of EtOAc, the mixture was washed with satd $\mathrm{NH}_{4} \mathrm{Cl}$ aq., satd $\mathrm{NaHCO}_{3}$ aq. and brine, dried over $\mathrm{Na}_{2} \mathrm{SO}_{4}$, and evaporated under reduced pressure. The residue was purified by column chromatography (silica gel, $n$-hexane-EtOAc) to give $\mathbf{1 7}(1.22 \mathrm{~g}, 60 \%$ yield) as an oil. ${ }^{1} \mathrm{H}$ NMR $\left(\mathrm{CDCl}_{3}\right) \delta 0.01,0.06$ (total $6 \mathrm{H}$, each s), $0.83(9 \mathrm{H}, \mathrm{s}), 0.92$ $(6 \mathrm{H}, \mathrm{t}, J=6.6 \mathrm{~Hz}), 1.17,1.18$ (total $3 \mathrm{H}$, each d, $J=6.8 \mathrm{~Hz}), 1.19(6 \mathrm{H}, \mathrm{d}$, $J=7.1 \mathrm{~Hz}), 1.26(3 \mathrm{H}, \mathrm{d}, J=7.1 \mathrm{~Hz}), 1.62-1.70(4 \mathrm{H}, \mathrm{m}), 1.85-1.96(1 \mathrm{H}, \mathrm{m})$, 2.52-2.65 (1H, m), 2.66-2.78 (1H, m), 2.94, 2.97 (total 3H, each s), $3.05(3 \mathrm{H}$, s), $3.10(3 \mathrm{H}, \mathrm{s}), 3.38,3.42$ (total $1 \mathrm{H}$, each dd, $J=10.8,9.3 \mathrm{~Hz}), 3.49-3.58(1 \mathrm{H}$, m), 3.56-3.60 $(1 \mathrm{H}, \mathrm{m}), 3.88-4.02(1 \mathrm{H}, \mathrm{m}), 4.07(0.5 \mathrm{H}, \mathrm{dd}, J=10.8,7.6 \mathrm{~Hz})$, $4.10(0.5 \mathrm{H}, \mathrm{dd}, J=10.8,7.3 \mathrm{~Hz}), 4.23-4.33(1 \mathrm{H}, \mathrm{m}), 4.35-4.43(1 \mathrm{H}, \mathrm{br})$, $4.58-4.68(1 \mathrm{H}, \mathrm{m}), 4.66,4.74$ (total $1 \mathrm{H}$, each $\mathrm{t}, J=7.5 \mathrm{~Hz}$ ), 5.66, 5.69 (total $1 \mathrm{H}$, each $\mathrm{ABq}, J=5.8 \mathrm{~Hz}$ ), 5.68, 5.80 (total $1 \mathrm{H}$, each $\mathrm{ABq}, J=5.6 \mathrm{~Hz}$ ), 5.84, 5.92 (total $1 \mathrm{H}$, each $\mathrm{ABq}, J=5.6 \mathrm{~Hz}$ ), $5.85,5.92$ (total $1 \mathrm{H}$, each $\mathrm{ABq}, J=5.8 \mathrm{~Hz}$ ).

1-Ethylpropyloxycarbonyloxymethyl (1R,5S,6S)-6-[(1R)-1-(tert-Butyldimethylsilyloxy)ethyl]-2-[(3S,5S)-5-(N,N-dimethylcarbamoyl)-1-(isobutyryloxymethyloxycarbonyl) pyrrolidin-3-ylthio]-1-methylcarbapen-2-em-3carboxylate (18). To a solution of $17(720 \mathrm{mg}, 0.880 \mathrm{mmol})$ in toluene $(8 \mathrm{ml})$ was added $\mathrm{MeP}(\mathrm{OEt})_{2}(1.00 \mathrm{~g}$, $7.35 \mathrm{mmol}$ ), and the mixture was stirred in a sealed tube at room temperature for $2 \mathrm{~h}$ under an Ar atmosphere. The mixture was evaporated under reduced pressure. A solution of the residue in xylene $(50 \mathrm{ml})$ was stirred in a sealed tube at $140-150{ }^{\circ} \mathrm{C}$ for $3 \mathrm{~h}$ under an $\mathrm{Ar}$ atmosphere. The mixture was evaporated under reduced pressure. The residue was purified by column chromatography (silica gel, $n$-hexane-EtOAc) to give an oil, which was solidified from $n$-hexane-EtOAc to give 18 (366 mg, 53\% yield) as a solid. ${ }^{1} \mathrm{H} \mathrm{NMR}\left(\mathrm{CDCl}_{3}\right) \delta 0.08,0.09$ (total $6 \mathrm{H}$, each s), $0.89(9 \mathrm{H}, \mathrm{s}), 0.92(6 \mathrm{H}, \mathrm{t}$, $J=7.3 \mathrm{~Hz}$ ) $1.17,1.18,1.19$ (total $6 \mathrm{H}$, each d, $J=7.1 \mathrm{~Hz}$ ), $1.23,1.24$ (total $6 \mathrm{H}$, each d, $J=5.8 \mathrm{~Hz}), 1.58-1.70(4 \mathrm{H}, \mathrm{m}), 1.88-2.00(1 \mathrm{H}, \mathrm{m}), 2.59,2.60$ (total $1 \mathrm{H}$, each q, J=7.1 Hz), 2.63-2.73 ( $1 \mathrm{H}, \mathrm{m}), 2.95,2.98$ (total $3 \mathrm{H}$, each s), $3.06(3 \mathrm{H}, \mathrm{s})$, $3.10(3 \mathrm{H}, \mathrm{s}), 3.19,3.20$ (total $1 \mathrm{H}$, each dd, $J=6.1,2.7 \mathrm{~Hz}), 3.23-3.34(1 \mathrm{H}, \mathrm{m})$, $3.43,3.46$ (total $1 \mathrm{H}$, each dd, $J=10.7,3.9 \mathrm{~Hz}), 3.56-3.71(1 \mathrm{H}, \mathrm{m}), 4.02(0.5 \mathrm{H}$, dd, $J=10.7,7.6 \mathrm{~Hz}), 4.12(0.5 \mathrm{H}, \mathrm{dd}, J=10.8,6.8 \mathrm{~Hz}), 4.19,4.22($ total $1 \mathrm{H}$, each dd, $J=9.8,1.9 \mathrm{~Hz}), 4.17-4.28(1 \mathrm{H}, \mathrm{m}), 4.62(1 \mathrm{H}$, quintet, $J=6.1 \mathrm{~Hz}), 4.68,4.74$ (total $1 \mathrm{H}$, each $\mathrm{t}, J=8.0 \mathrm{~Hz}$ ), 5.66, 5.69 (total $1 \mathrm{H}$, each $\mathrm{ABq}, J=5.6 \mathrm{~Hz}$ ), 5.68 , 5.81 (total $1 \mathrm{H}$, each $\mathrm{ABq}, J=5.6 \mathrm{~Hz}$ ), 5.87, 5.89 (total $1 \mathrm{H}$, each $\mathrm{ABq}, J=5.6 \mathrm{~Hz}$ ).

1-Ethylpropyloxycarbonyloxymethyl (1R,5S,6S)-2-[(3S,5S)-5-(N,N-Dimethylcarbamoyl)-1-(isobutyryloxymethyloxycarbonyl)pyrrolidin-3-ylthio]-6-[(1R)-1-hydroxyethyl-1-methylcarbapen-2-em-3-carboxylate (8). Compound $\mathbf{8}$ was obtained as a white solid ( $208 \mathrm{mg}, 72 \%$ yield) from 18 (337 $\mathrm{mg}, 0.429 \mathrm{mmol})$ in a similar manner to that described in the synthesis of $\mathbf{4}$ in Scheme 3.

\section{Determination of water solubility}

MEPM (5 mg), and its single- and double-promoiety prodrugs were weighed and vigorously shaken for $30 \mathrm{~min}$ at room temperature in Britton-Robinson buffer ( $\mathrm{pH}$ 7.0). After centrifugation at 3000 r.p.m. for $10 \mathrm{~min}$ and filtration using DISMIC-13HP $(0.45 \mathrm{~mm}$, Toyo Roshi Kaisha, Tokyo, Japan), concentrations of the compounds in the filtrate were determined using HPLC, consisting of a pump (PU-980; JASCO, Tokyo, Japan), a UVdetector (UV-970; JASCO), an autosampler (AS-950; JASCO) and DevelosilODS-UG-5 ( $5 \mathrm{~mm}, 4.6 \times 150 \mathrm{~mm}$; Nomura Chemical, Seto, Japan).

\section{Determination of $\log D$}

Octanol-water partition coefficients were determined and $\log \mathrm{D}$ values were calculated as an index of lipophilicity. Test compounds $(1 \mathrm{mg})$ were dissolved in $1 \mathrm{ml}$ octanol and mixed with $1 \mathrm{ml}$ Britton-Robinson buffer ( $\mathrm{pH} 7.0$ ). The mixed solution was vigorously shaken at room temperature for $30 \mathrm{~min}$ and then centrifuged at 3000 r.p.m. for $10 \mathrm{~min}$. Concentrations in the octanol fraction and buffer fraction were determined using the HPLC described above.

\section{Oral absorption in rats}

Male SD rats (217-238g) were used to determine plasma concentrations of MEPM after oral administration of MEPM, and its single- and doublepromoiety prodrugs. The animals were starved overnight before dosing, but were allowed to drink water. Test compounds were dissolved in 1.5\% SDS, and administered orally at $20 \mathrm{mg}$ potency per $\mathrm{kg}$. Blood was collected from the jugular vein at 30,60 and $180 \mathrm{~min}$ after oral dosing, and the blood was centrifuged at 3000 r.p.m. for $10 \mathrm{~min}$ at $4{ }^{\circ} \mathrm{C}$. Concentrations of MEPM in the plasma were determined using the HPLC as described above.

\section{Pharmacokinetic evaluation in rats and beagles}

Pharmacokinetic evaluations were performed in male SD rats (192-211 g) and beagles $(9.0-11.0 \mathrm{~kg})$. The animals were starved overnight before dosing, but were allowed to drink water. Test compounds were dissolved in $1.5 \%$ SDS and administered orally to rats at a dose of $20 \mathrm{mg}$ potency per $\mathrm{kg}$, and to beagles at a dose of $10 \mathrm{mg}$ potency per $\mathrm{kg}$, respectively. Blood was collected from the jugular vein at 10,20, 30, 45, 60, 90 and $120 \mathrm{~min}$ in rats, and at $0.25,0.5,1,3,5$, 8 and $12 \mathrm{~h}$ in beagles after dosing, respectively. MEPM was dissolved in saline, and administered intravenously to rats at a dose of $2 \mathrm{mg}$ potency per $\mathrm{kg}$, and to beagles at a dose of $1 \mathrm{mg} \mathrm{kg}^{-1}$, respectively. Blood was collected from the jugular vein at 5, 10, 15, 20 and $30 \mathrm{~min}$ in rats and at $0.25,0.5,1,3,5,8 \mathrm{~h}$ in beagles, respectively. Blood was centrifuged at 3000 r.p.m. for $10 \mathrm{~min}$ at $4{ }^{\circ} \mathrm{C}$. Concentrations of MEPM in the plasma were determined by HPLC as described above

1 Nicolau, D. P. Carbapenems: a potent class of antibiotics. Expert Opin. Pharmacother. 9, 23-37 (2008).

2 Bassetti, M., Nicolini, L., Esposito, S., Righi, E. \& Viscoli, C. Current status of newer carbapenems. Curr. Med. Chem. 16, 564-575 (2009)

3 Neu, H. C. \& Labthavikul, P. Comparative in vitro activity of $\mathrm{N}$-formimidoyl thienamycin agent Gram-Positive and Gram-Negative aerobic and anaerobic species and its $\beta$-lactamase stability. Antimicrob. Agents Chemother. 21, 180-187 (1982).

4 Neu, H. C., Chin, N., Saha, G. \& Labthavikul, P. In vitro activity against aerobic and anaerobic Gram-Positive and Gram-Negative Bacteria and $\beta$-lactamase stability of RS-533, a novel carbapenem. Antimicrob. Agents Chemother. 30, 828-834 (1986).

$5 \mathrm{Neu}, \mathrm{H}$. C., Novelli, A. \& Chin, N. In vitro activity and $\beta$-lactamase stability of a new carbapenem, SM-7338. Antimicrob. Agents Chemother. 33, 1009-1018 (1989).

6 Alvarez-Lerma, F., Grau, S. \& Ferrandez, O. Characteristics of doripenem: a new broadspectrum antibiotic. Drug Des. Devel. Ther. 3, 173-190 (2009).

7 Park, S. W., We, J. S., Kim, G. W., Choi, S. H. \& Park, H. S. Stability of new carbapenem DA-1131 to renal dipeptidase (dehydropeptidase I). Antimicrob. Agents Chemother. 46, 575-577 (2002).

8 Mori, M., Hikida, M., Nishihara, T., Nasu, T. \& Mitsuhashi, S. Comparative stability of carbapenem and penem antibiotics to human recombinant dehydropeptidase-I. J. Antimicrob. Chemother. 37, 1034-1036 (1996).

9 Hikida, M., Kawashima, K., Yoshida, M. \& Mitsuhashi, S. Inactivation of new carbapenem antibiotics by dehydropeptidase-I from porcine and human renal cortex. J. Antimicrob. Chemother. 30, 129-134 (1992).

10 Fung-Tomc, J. C. et al. Structure-activity relationships of carbapenems that determine their dependence on porin protein D2 for activity against Pseudomonas aeruginosa. Antimicrob. Agents Chemother. 39, 394-399 (1995).

11 Fukuda, T. et al. In vitro and In vivo antibacterial activity of CS-834, a novel oral carbapenem. Antimicrob. Agents Chemother. 41, 2652-2663 (1997).

12 Kumagai, T., Tamai, S., Abe, T. \& Hikida, M. Current status of oral carbapenem development. Curr. Med. Chem. Anti-Infective Agents 1, 1-14 (2002).

13 Kobayashi, R. et al. In vitro activity of tebipenem, a new oral carbapenem antibiotic, against Penicillin-nonsusceptible Streptococcus pneumoniae. Antimicrob. Agents Chemother. 49, 889-894 (2005).

14 Miyazaki, S. et al. In vitro and In vivo antibacterial activities of L-084, a novel oral carbapenem, against causative organisms of respiratory tract infections. Antimicrob. Agents Chemother. 45, 203-207 (2001).

15 Hikida, M., Itahashi, K., Igarashi, A., Shiba, T. \& Kitamura, M. In vitro antibacterial activity of LJC 11,036, an active metabolite of L-084, a new oral carbapenem antibiotic with potent Antipneumococcal Activity. Antimicrob. Agents Chemother. 43, 2010-2016 (1999).

16 Baldwin, C. M., Lyseng-Williamson, K. A. \& Keam, S. J. Meropenem a review of its use in the treatment of serious bacterial infections. Drugs 68, 803-838 (2008).

17 Kasai, M. et al. AS-924, a novel bifunctional prodrug of ceftizoxime. J. Antibiot. 52, 491-500 (1999). 
18 Kasai, M. et al. AS-924, a novel orally active bifunctional prodrug of ceftizoxime. Synthesis and relationship between physicochemical properties and oral absorption. Chem. Pharm. Bull. 47, 1081-1088 (1999).

19 Abrahamsson, K. et al. Pivalic acid-induced carnitine deficiency and physical exercise in humans. Metab. Clin. Exp. 45, 1501-1507 (1996).

20 Alexander, J., Cargill, R., Michelson, S. R. \& Schwam, H. (Acyloxy)alkyl carbamates as novel bioreversible prodrugs for amines: increased permeation through biological membranes. J. Med. Chem. 31, 318-322 (1988).

21 Matsumura, H., Bando, T. \& Sunagawa, M. An efficient synthesis of $(2 S, 4 S)-2$ substituted-4-mercaptopyrrolidine derivatives. Heterocycles 41, 147-159 (1995).
22 Mori, M. \& Oida, S. A short-step synthesis of orally active carbapenem antibiotic CS-834. Chem. Pharm. Bull. 48, 126-130 (2000).

23 Matsumoto, F. \& Oizumi, K. Cefuroxime axetil. Jpn. J. Antibiot. 41, 1181-1193 (1988).

24 Totsuka, K. et al. Effects of food intake and age on the pharmacokinetics of AS-924, a novel ester-type cephem antibiotic. Comparison with cefpodoxime proxetil. Int. J. Antimicrob. Agents 18, 463-469 (2001).

25 Miyazaki, S. et al. Novel orally active prodrugs of meropenem, KL-3744 and KL-3758: prediction of their efficacy for causative pathogens of respiratory tract infections (RTIs). Abstract book of 43rd Annual Interscience Conference of Antimicrobial Agents and Chemotherapy, 231 (2003). 